


\title{
PAS Aanvullende reservemaatregelen Landbouw: uitwerking van een Quick scan
}

\author{
K. Groenestein ${ }^{1}$ \\ P. Bikker ${ }^{1}$ \\ C. van Bruggen ${ }^{2}$ \\ H. Ellen ${ }^{1}$ \\ J. van Harn ${ }^{1}$ \\ J. Huijsmans ${ }^{3}$ \\ N. Ogink ${ }^{1}$ \\ L. Şebek ${ }^{1}$ \\ I. Vermeij ${ }^{1}$ \\ ${ }^{1}$ Wageningen Livestock Research \\ ${ }^{2}$ CBS \\ ${ }^{3}$ Wageningen Plant Research International
}


Groenestein, K., Bikker, P., Bruggen, van C., Ellen, H., Harn van, J., Huijsmans, J., Ogink, N., Şebek, L. en I. Vermeij, 2017. PAS Aanvullende reservemaatregelen Landbouw: uitwerking van een Quick scan. Wageningen Livestock Research, Rapport 1145.

\section{Samenvatting}

De stikstofdepositie in veel Natura 2000-gebieden in Nederland is hoger dan gewenst. Dit heeft geleid tot een impasse in economische ontwikkeling van onder meer de veehouderij. Het interdepartementale Programma Aanpak Stikstof (PAS) heeft tot doel de vastgelopen vergunningverlening weer vlot te trekken en ervoor te zorgen dat op termijn de instandhoudingsdoelstellingen van de natuurgebieden kunnen worden gehaald. Voor de drie sectorclusters Verkeer en Vervoer, Industrie en Energie en de Landbouw worden daarom bronmaatregelen geïnventariseerd om knelpunten op te vangen. In opdracht van het Ministerie van Economische Zaken is dit de inventarisatie van maatregelen voor de landbouwsector.

\section{Summary}

In many Natura 2000 area's, the nitrogen deposition is higher than wished for. This led to a deadlock in economic development of, among others, livestock husbandry. The interdepartmental program 'Programma Aanpak Stikstof' (PAS), is meant to overcome the standstill of grants of permits to produce, while in term preservation goals of nature area's can be achieved. For the three sector groups Traffic and Transportation, Industry and Energy, and Agriculture source measures are inventoried to deal with the bottlenecks. By order of the Ministry of Economic Affairs this report presents the inventory of measures for agriculture.

Dit rapport is gratis te downloaden op https://doi.org/10.18174/469068 of op www.wur.nl/livestock-research (onder Wageningen Livestock Research publicaties).

\section{(C) 2017 Wageningen Livestock Research}

Postbus 338, 6700 AH Wageningen, T 03174839 53, E info.livestockresearch@wur.nl, www.wur.nl/livestock-research. Wageningen Livestock Research is onderdeel van Wageningen University \& Research.

Wageningen Livestock Research aanvaardt geen aansprakelijkheid voor eventuele schade voortvloeiend uit het gebruik van de resultaten van dit onderzoek of de toepassing van de adviezen.

Alle rechten voorbehouden. Niets uit deze uitgave mag worden vermenigvuldigd en/of openbaar gemaakt worden door middel van druk, fotokopie, microfilm of op welke wijze dan ook zonder voorafgaande toestemming van de uitgever of auteur.

Wageningen Livestock Research is NEN-EN-ISO 9001:2015 gecertificeerd.

Op al onze onderzoeksopdrachten zijn de Algemene Voorwaarden van de Animal Sciences Group van toepassing. Deze zijn gedeponeerd bij de Arrondissementsrechtbank Zwolle. 


\section{Inhoud}

3.1 Pluimvee

3.1.1 Factsheet 1. Dagontmesting met mestbandsystemen 8

3.1.2 Factsheet 2. Turfstrooisel 9

3.1.3 Factsheet 3. By-pass van luchtwasser 11

3.2 Rundvee 12

3.2.1 Factsheet 4. Verbetering mestschuiven met nieuwe schuiven 12

3.2.2 Factsheet 5. Bolle rubberen coating roostervloer 14

3.2.3 Factsheet 6. Ureaseremmers $\quad 15$

3.2.4 Factsheet 7. Ventilatiemanagement gericht op beperkt debiet 16

3.2.5 Factsheet 8. Luchtmixen van opgeslagen mest 18

3.2.6 Factsheet 9. Luchtzuivering in de nok 20

3.2.7 Factsheet 10. Luchtzuivering van lucht uit de kelder 21

$\begin{array}{lll}4.1 & \text { Pluimvee } & 23\end{array}$

4.1.1 Factsheet 11. Eiwitgift op maat met hele tarwekorrel voor vleeskuikens 24

4.1.2 Factsheet 12. Verfijning van fasevoedering bij vleeskuikens 26

4.1.3 Factsheet 13. Verlagen ruw eiwitgehalte vleeskuikens 28

4.1.4 Factsheet 14. Verlagen eiwitgehalte voer van leghennen 30

4.2 Varkens $\quad 32$

4.2.1 Factsheet 15. Verlagen van eiwit in voer van zeugen met biggen 32

4.2.2 Factsheet 16. Toevoegen benzoëzuur aan het voer van biggen 34

4.2.3 Factsheet 17. Verlagen van eiwit in voer van vleesvarkens 35

4.2.4 Factsheet 18. Toevoegen van benzoëzuur aan voer van vleesvarkens 36

$\begin{array}{lll}4.3 & \text { Rundvee } & 37\end{array}$

4.3.1 Factsheet 19. TAN-excretie melkvee verminderen via voerspoor 37

5.1 Algemeen $\quad 39$

5.1.1 Factsheet 20. Aanzuren van mest en zodenbemesting 39

5.1.2 Factsheet 21. Verbeteren van effectiviteit van toedieningstechnieken $\quad 41$

5.1.3 Factsheet 22. Mestinjectie op grasland 43

5.1.4 Factsheet 23. Emissiebeperkende weersomstandigheden 44

Bijlage 1 Groslijst van maatregelen reservepakket

Bijlage 2 Referentiesysteem t.b.v. ammoniakemissiereductie berekening van Factsheet 1: Dagontmesting emt mestbandsystemen

Bijlage 3 Achtergrondinformatie bij Factsheet 19: TAN-excretie verminderenop het melkveebedrijf met voermaatregelen 



\section{$1 \quad$ Inleiding}

Rond Natura 2000-gebieden die zwaar met stikstof zijn belast, werden op grond van de Natuurbeschermingswet $1998^{1}$ nauwelijks nog nieuwe vergunningen verleend voor activiteiten die leiden tot een toename van de depositie van stikstof in voor stikstof gevoelige habitats in Natura 2000-gebieden. De stikstofdepositie is namelijk in veel gevallen hoger dan voor de natuurdoelen als gewenst wordt beschouwd. Dit heeft geleid tot een impasse in economische ontwikkeling van onder meer de veehouderij. Het interdepartementale Programma Aanpak Stikstof (PAS) heeft tot doel de vastgelopen vergunningverlening weer vlot te trekken en ervoor te zorgen dat op termijn de instandhoudingsdoelstellingen van de natuurgebieden kunnen worden gehaald. Het PAS zorgt ervoor dat er in en rond de Natura 2000-gebieden weer ruimte komt voor economische ontwikkeling, terwijl tegelijkertijd wordt zeker gesteld dat de natuurkwaliteit in die gebieden behouden blijft of waar nodig beter wordt.

Door de PAS-partners is afgesproken een breed reservepakket te ontwikkelen met maatregelen die generiek of lokaal inzetbaar zijn om emissies van stikstofverbindingen te reduceren. Dit voornemen is als volgt in het PAS vastgelegd (Paragraaf 6.3.2, pag.54):

'Er is een pakket met maatregelen in ontwikkeling voor het geval er in de toekomst alsnog knelpunten ontstaan in ontwikkelingsruimte of in herstel van de natuur. Hierbij wordt met de partners van het programma aanpak stikstof en de belanghebbende partijen gekeken naar alle kosteneffectieve maatregelen bij stikstof emitterende activiteiten en herstelmaatregelen alsmede naar de haalbaarheid en betaalbaarheid van maatregelen.'

Het Ministerie van Economische Zaken (EZ) heeft samen met het Ministerie van Infrastructuur en Milieu (IenM) en het Interprovinciaal Overleg (IPO) een traject uit gezet waarin voor 3 clusters van sectoren geïnventariseerd is welke bronmaatregelen in beeld kunnen komen voor opname in dit reservepakket. Dit betreft de volgende sectorclusters: Verkeer en Vervoer, Industrie en Energie en de Landbouw. De PAS-partners hebben daarnaast ook ruimte geboden om maatregelen in te kunnen zetten in het kader van convenanten of overeenkomsten op basis van het 'voor wat, hoort wat' principe. De overeenkomst generieke maatregelen die in 2014 met de landbouwsectoren is afgesloten is hier een voorbeeld van. De inventarisatie van maatregelen is in handen gegeven van kennisorganisaties die als autoriteit voor hun sectoren gelden. Voor de landbouwsector heeft de WUR deze inventarisatie uitgevoerd op basis van expertmeetings met vertegenwoordigers van betreffende relevante sectoren.

In de expertmeeting van 15 december 2016 voor de landbouwsector is met een brainstorm een inventarisatie gemaakt van maatregelen. Deze maatregelen zijn benoemd in de groslijst (zie Bijlage 1) en vormt het uitgangspunt voor de verdere uitwerking voor de sector landbouw. Binnen deze groslijst heeft het Ministerie van Economische Zaken (EZ) maatregelen geprioriteerd die een eerste uitwerking behoeven.

De doelstelling van dit project betreft het bij elkaar brengen van bestaande kennis en expertinzichten op het gebied van NH3-emissiereducerende maatregelen in de landbouw. De maatregelen worden beoordeeld op de volgende criteria:

- $\quad$ kosten en kosteneffectiviteit;

- $\quad$ tijdpad van implementatie;

- $\quad$ afdwingbaarheid en instrumentatie;

- draagvlak bij sector: welke technische belemmeringen zijn te voorzien en of stimuleringsmaatregelen nodig zijn.

\footnotetext{
${ }^{1}$ Per 1-1-2017 is de Natuurbeschermingswet 1998 opgegaan in de Wet natuurbescherming.
} 


\section{Factsheets Maatregelen}

De volgende paragrafen bevatten factsheets met een beschrijving van maatregelen die generiek inzetbaar zijn om ammoniakemissie uit de landbouw te reduceren. De selectie bestaat uit door EZ geprioriteerde maatregelen uit de brainstorm en is gebaseerd op de technische mogelijkheid van de maatregel nu of in de nabije toekomst. Of technologische mogelijkheden ook ten volle zullen worden ingezet door de sector wordt niet besproken, omdat daar geen kwantitatieve gegevens aan gekoppeld kunnen worden. Wel wordt kwalitatief aangegeven of het gewenst is stimuleringsmaatregelen toe te passen om een maatregel ten volle te benutten. De voermaatregelen bijvoorbeeld, zitten vaak op de grens van wat met de huidige inzichten technisch mogelijk is. De vraag of boeren daadwerkelijk op het scherpst van de snede gaan voeren, wordt in dit rapport niet beantwoord. De beschrijving van de maatregel geeft ook de context aan waarbinnen die moet of kan worden toegepast. Dit kan bijvoorbeeld van belang zijn om te voorkomen dat andere ongewenste gassen kunnen ontstaan of dat productieresultaten onder de maatregel zouden kunnen leiden.

De emissiedaling op nationale schaal is met het Nationaal Emissiemodel Agriculture (NEMA) berekend in kton $\mathrm{N} / \mathrm{jaar}$ door de hele mestketen heen. Dat betekent dat wanneer een emissie reducerende maatregel in de stal tot gevolg heeft dat meer $\mathrm{N}$ in de mest achterblijft, een deel van deze winst verloren gaat tijdens opslag en bij het uitrijden van de mest. Dit is verdisconteerd in de berekeningen. Tevens is berekend wat het effect zou zijn bij 100\% implementatie aangezien het generieke maatregelen betreft, mits technisch haalbaar. Wanneer maatregelen bijvoorbeeld alleen in nieuwbouw gerealiseerd kunnen worden is dat in 2030 niet haalbaar met een vernieuwingspercentage van 4\% per jaar.

De kosteneffectiviteit is berekend door de jaarkosten van een maatregel te delen door de emissiedaling uitgedrukt in kton $\mathrm{N} / \mathrm{jaar}$. De jaarkosten zijn inclusief de jaarlijkse afschrijving van de investering die ook is opgenomen in de factsheet.

De tijdgebondenheid die in de factsheets wordt gegeven is enkel gebaseerd op technische mogelijkheden of beperkingen gegeven de huidige markt. Een voorbeeld hiervan is de invoering van een rubberen toplaag op de roostervloeren in rundveestallen omdat er momenteel maar één leverancier is. De levering is derhalve beperkend voor de invoeringssnelheid van de maatregel. Hoe de markt zich in de toekomst kan ontwikkelen afhankelijk van patenten en juridische eigendommen is niet meegenomen. Een ander voorbeeld is wanneer nieuwbouw vereist is voor een maatregel. Dan wordt gesteld dat de afschrijving van een gebouw 25 jaar is. Dat betekent dat per jaar $4 \%$ van de stallen vervangen worden. Uiteindelijk zullen alle maatregelen voor 2030 doorberekend worden alsof ze door $100 \%$ van de stallen worden opgenomen (generiek), tenzij dat niet mogelijk is.

De huisvestingsmaatregelen zijn op het moment van deze rapportage niet opgenomen in de Regeling ammoniak en veehouderij (Rav) in het kader van het Besluit Emissiearme Huisvesting (BEH). Mogelijk dat dat in de toekomst wel gebeurt. Een deel van de voedingsmaatregelen zijn momenteel als onderdeel van de stoppersregeling opgenomen voor bedrijven die op korte termijn willen stoppen om te voorkomen dat die nog stalinvesteringen moeten doen. De toedieningsmaatregelen behelzen combinaties van bestaande technieken en management en een enkele nieuwe techniek; voor een deel zijn dit nog niet erkende methoden.

Per factsheet wordt een korte toelichting en onderbouwing gegeven. Bij een uitgebreide technische onderbouwing wordt verwezen naar een bijlage. De toelichting per factsheet behelst de maatregel zelf, aspecten rondom praktische implementatie en de kostenberekening. Er wordt op dit moment geen rekening gehouden met het feit of NEMA, waarmee de effecten van de maatregelen gemonitord worden, is toegerust qua statistieken en procedures, om dit daadwerkelijk te berekenen. Dat zal indien noodzakelijk in een later stadium beschouwd worden. 
T.a.v. de afdwingbaarheid en instrumentatie is de beoordeling op technische gronden gebaseerd, waarbij gebruik is gemaakt van de kennis van de sector en haar bedrijfseconomische afwegingen.

Sociaal maatschappelijke of beleidsmatige argumenten zijn niet meegenomen. 


\section{Huisvestingsmaatregelen}

\subsection{Pluimvee}

\subsubsection{Factsheet 1. Dagontmesting met mestbandsystemen}

\section{Dagontmesting met mestbandsystemen i.c.m. een droogtunnel in pluimveestallen}

Dit systeem is toepasbaar voor pluimveestallen met mestbandsystemen: kooi- en volièresystemen voor leghennen (E 2) en opfokleghennen (E 1)

Deze maatregel kent geen droging in de stal, binnen 24 uur wordt de mest via banden afgedraaid en in de droogtunnel gebracht. Daar wordt de mest gedroogd tot minimaal $80 \%$ drogestof.

\begin{tabular}{|c|c|c|}
\hline & 2020 & 2030 \\
\hline Bij landelijke maatregelen: emissiedaling (kton N/jr) & 0,6 & 1,4 \\
\hline $\begin{array}{l}\text { Implementatie } \\
\text { (kosteneffectiviteit en tijdpad) }\end{array}$ & 2020 & 2030 \\
\hline Kosteneffectiviteit (mln $€ /$ kton $\mathrm{N}$ ) & 7,0 & 10,3 \\
\hline Investeringskosten voor de sector ( $\mathrm{mln} €$ ) & 32 & 103 \\
\hline Operationele kosten voor de sector ( $\mathrm{mln} € / \mathrm{jr}$ ) & 4,3 & 13,9 \\
\hline Tijd benodigd voor invoering maatregel (jr) & \multicolumn{2}{|c|}{$\begin{array}{l}\text { Afhankelijk van uitgangssituatie en type } \\
\text { pluimvee (Zie Bijlage } 1 \text { ) }\end{array}$} \\
\hline Termijn waarop effect wordt bereikt (jr) & \multicolumn{2}{|c|}{ Direct effect bij implementatie } \\
\hline \multicolumn{3}{|l|}{ Afdwingbaarheid en instrumentatie } \\
\hline $\begin{array}{l}\text { Verplicht in te voeren via wet- en regelgeving } \\
(\mathrm{ja} / \mathrm{nee})\end{array}$ & \multicolumn{2}{|l|}{$\mathrm{Ja}$} \\
\hline $\begin{array}{l}\text { Vrijwillig in te voeren via kennisdeling en stimulering } \\
\text { (ja/nee) }\end{array}$ & \multicolumn{2}{|c|}{$\begin{array}{l}\text { Ja en Nee. De verwachting is dat de } \\
\text { ontwikkeling tot } 2020 \text { autonoom en o.i.v. } \\
\text { Besluit emissiearme huisvesting plaats zal } \\
\text { vinden. Voor ontwikkeling na } 2020 \text { wordt } \\
\text { verwacht dat een stimuleringsregeling nodig } \\
\text { zal zijn. }\end{array}$} \\
\hline Vrijwillige afspraak (ja/nee) & \multicolumn{2}{|c|}{ Afhankelijk van de afzetbaarheid van de mest. } \\
\hline
\end{tabular}

\section{Toelichting maatregel}

In Bijlage 1 wordt nader ingegaan op de stalsystemen die als referentie dienen en de huidige en toekomstige implementatie van de afzonderlijke referentiesystemen en maatregelen voor volière, kooi- en grondhuisvesting. Deze maatregel vereist een droogtunnel als nageschakelde techniek. De emissiereductie in de stal wordt dus deels teniet gedaan door de extra emissie die ingerekend wordt voor de droogtunnel (type E 6.4 in de Rav) met een additionele emissie van 0.001 en $0.002 \mathrm{~kg} / \mathrm{jaar}$ per dierplaats voor respectievelijk opfokleghennen en leghennen.

De huidige emissiefactoren in de Rav zijn voor de droogtunnels en de volièresystemen te laag (Ellen et al., 2017). Betere cijfers zijn echter nog niet voorhanden. De berekende reducties zijn daarom onderschattingen van de werkelijke reducties. Echter, om tot een gewenst emissieniveau te komen moeten de hogere emissies van pluimvee ook weer door de PAS gecompenseerd worden. Daarom hanteren we toch de beschikbare (te lage) emissiefactoren in de huidige Rav. 


\section{Toelichting praktische implementatie}

Ca $20 \%$ van de leghennen zit in 2012-2014 nog op grondhuisvesting. Deze zullen niet omschakelen naar dagontmesting. Enerzijds omdat ze geen mestband hebben (op E 2.12.1 na), anderzijds is de verwachting dat boeren met grondhuisvesting bij noodzaak van investeren om zullen schakelen naar volièrehuisvesting.

Het drogen in de droogtunnel is een continu proces, want de mest moet binnen 24 uur droog genoeg zijn om te voorkomen dat de urinezuur in de mest wordt omgezet in ammoniak.

\section{Toelichting kosten}

Bij 80\% van de dieren moeten tot 2030 nog droogtunnels gebouwd worden, waarvan $45 \%$ reeds in 2020 (Bijlage 1). Er wordt vanuit gegaan dat per 45.000 dieren (gemiddelde bedrijfsgrootte) één droogtunnel geplaatst wordt.

Operationele kosten van de droogtunnel zijn de versnelde afschrijving, rente, dagelijkse energiekosten: $300 \mathrm{MJ} / 1000$ eieren (Ellen, mondelinge mededeling) en onderhoud .

\subsubsection{Factsheet 2. Turfstrooisel}

\section{Toepassing turfstrooisel in vleeskuikenstallen}

Vleeskuikens worden gehouden op strooisel. Deze maatregel betekent dat in plaats van houtkrullen of zaagsel, turf zal worden gebruikt als strooiselmateriaal. Dit zal een verzuring van de mest veroorzaken waardoor emissie van ammoniak afneemt.

De verwachting is dat het toepassen van turfstrooisel leidt tot een reductie van $25 \%$, maar dit moet door metingen nog gevalideerd worden.

\begin{tabular}{|c|c|c|}
\hline Effectiviteit reductie & 2020 & 2030 \\
\hline Bij landelijke maatregelen: emissiedaling (kton $\mathrm{N} / \mathrm{jr}$ ) & 0.2 & 0.5 \\
\hline $\begin{array}{l}\text { Implementatie } \\
\text { (kosteneffectiviteit en tijdpad) }\end{array}$ & 2020 & 2030 \\
\hline Kosteneffectiviteit (M€/kton $\mathrm{N}$ ) & 7,7 & 7,7 \\
\hline Investeringskosten voor de sector (M€) & - & - \\
\hline Operationele kosten voor de sector ( $\mathrm{M} € / \mathrm{jr}$ ) & 1,6 & 4,0 \\
\hline Tijd benodigd voor invoering maatregel (jr) & \multicolumn{2}{|c|}{$40 \%$ in 2020 en $100 \%$ in 2030} \\
\hline Termijn waarop effect wordt bereikt (jr) & \multicolumn{2}{|l|}{$2019-2023$} \\
\hline \multicolumn{3}{|l|}{ Afdwingbaarheid en instrumentatie } \\
\hline $\begin{array}{l}\text { Verplicht in te voeren via wet- en regelgeving } \\
\text { (ja/nee) }\end{array}$ & \multicolumn{2}{|c|}{$\begin{array}{l}\text { Ja, is geschikt als reducerende } \\
\text { managementmaatregel, in bijlage } 2 \text { van de } \\
\text { Rav. }\end{array}$} \\
\hline $\begin{array}{l}\text { Vrijwillig in te voeren via kennisdeling en stimulering } \\
\text { (ja/nee) }\end{array}$ & \multicolumn{2}{|c|}{$\begin{array}{l}\text { Ja, in combinatie met stimulering is vrijwillige } \\
\text { implementatie te verwachten omdat deze } \\
\text { maatregel positief uitwerkt op voorkomen } \\
\text { voetzool-laesies. }\end{array}$} \\
\hline Vrijwillige afspraak (ja/nee) & \multicolumn{2}{|c|}{$\begin{array}{l}\text { Ja, maatregel wordt al op kleine schaal } \\
\text { toegepast, zie hierboven. }\end{array}$} \\
\hline
\end{tabular}




\section{Toelichting maatregel}

Voor strooiselmateriaal in vleeskuikenstallen wordt hoofdzakelijk gebruik gemaakt van houtkrullen. Eerder is aangetoond dat het toepassen van gedroogde snijmais i.p.v. houtkrullen tot emissiereductie leidt als gevolg van het zure karakter van dit gefermenteerde product (Van Harn et al., 2015). Een andere mogelijkheid om emissie op een soortgelijke manier te reduceren is turfstrooisel. Dit materiaal wordt momenteel al op een beperkte schaal gebruikt in de vleeskuikenstallen omdat het een positieve uitwerking heeft op het voorkomen van voetzool-laesies, daarmee werkt het dierwelzijns verhogend.

De maatregel bestaat uit:

- $\quad$ het aanbrengen van turfstrooisel bij de start van de opfokronde van vleeskuikens. De ammoniakemissie uit de bodem wordt hier naar verwachting afgeremd door de hoge zuurgraad van het turfstrooisel. Het emissie reducerende effect is nog niet vastgesteld via praktijkmetingen. De verwachting is dat het toepassen van turfstrooisel leidt tot een reductie van $25 \%$.

Het emissie-reducerend effect van het gebruik van gedroogde snijmais als strooisel in plaats van houtkrullen bedroeg 37\% (Van Harn et al., 2015) Conservatief geschat wordt hier gerekend met een reductie door het gebruik van turfstrooisel van $25 \%$.

\section{Toelichting praktische implementatie}

De maatregel is toepasbaar in bestaande vleeskuikenstallen waar nu houtkrullen als strooisel wordt gebruikt (E 5.6, 5.10, 5.11, 5.14 en 5.100). Na het vaststellen van het emissie-reducerende effect kan de maatregel geïmplementeerd worden vanaf 2019 en zal dan enige jaren vergen (2019 - 2023).

\section{Toelichting kosten}

Turfstrooisel is in aanschaf niet duurder dan houtkrullen, maar is vochtiger, waardoor er meer gestookt moet worden om droog strooisel te krijgen. Inschatting is dat dit voor een bedrijf met 90.000 vleeskuikens ca. $€ 8.000$ per jaar kost, ofwel $€$ 0,09 per dierplaats per jaar (Van Harn et. al (2011), artikel in Pluimveehouderij 25 november 2011). In Nederland werden gemiddeld 45 miljoen vleeskuikens gehouden (2012-2014, Bron CBS). Jaarkosten dus $€ 4$ miljoen. In 2020 kan $40 \%$ van de bedrijven dit geïmplementeerd hebben, dus in $2020 € 1,6$ miljoen.

Er is dus vanuit gegaan dat turfstrooisel als materiaal niet duurder is dan houtkrullen. Bij grootschalige toepassing zou schaarste kunnen ontstaan, los van het feit of ontginning van veen wenselijk is. Dit kan prijsopdrijvend werken en is niet ingecalculeerd. 


\subsubsection{Factsheet 3. By-pass van luchtwasser}

\section{Toepassing gedeeltelijke luchtzuivering in vleeskuikenstallen}

De maatregel behelst het toepassen van behandeling van een deel van de afgevoerde ventilatielucht met daarnaast een onbehandelde bypass-stroom.

Wanneer de luchtwasser gedimensioneerd wordt op 50\% van de maximale ventilatiecapaciteit zal slechts $15 \%$ van de lucht onbehandeld de stal verlaten. Met een chemische luchtwasser die $90 \%$ van de ammoniak uit de lucht kan verwijderen, wordt dan in totaal 75\% ammoniakemissie gereduceerd.

\begin{tabular}{|c|c|c|}
\hline Effectiviteit reductie & 2020 & 2030 \\
\hline Bij landelijke maatregelen: emissiedaling (kton N/jr) & 0,4 & 0,8 \\
\hline $\begin{array}{l}\text { Implementatie } \\
\text { (kosteneffectiviteit en tijdpad) }\end{array}$ & 2020 & 2030 \\
\hline Kosteneffectiviteit $(€ /$ kton $N)$ & 34 & 34 \\
\hline Investeringskosten voor de sector (M€) & 45 & 90 \\
\hline Operationele kosten voor de sector (M€/jr) & 13,5 & 27 \\
\hline Tijd benodigd voor invoering maatregel (jr) & \multicolumn{2}{|l|}{ Vanaf 2018} \\
\hline Termijn waarop effect wordt bereikt (jr) & \multicolumn{2}{|c|}{$50 \%$ in 2020 en $100 \%$ in 2030} \\
\hline \multicolumn{3}{|l|}{ Afdwingbaarheid en instrumentatie } \\
\hline $\begin{array}{l}\text { Verplicht in te voeren via wet- en regelgeving } \\
\text { (ja/nee) }\end{array}$ & \multicolumn{2}{|c|}{ Ja, kan in bijlage 1 van de Rav. } \\
\hline $\begin{array}{l}\text { Vrijwillig in te voeren via kennisdeling en stimulering } \\
\text { (ja/nee) }\end{array}$ & \multicolumn{2}{|c|}{$\begin{array}{l}\text { Ja, stimulering kan leiden tot verhoging } \\
\text { implementatie-niveau. }\end{array}$} \\
\hline Vrijwillige afspraak (ja/nee) & \multicolumn{2}{|l|}{ Nee. } \\
\hline
\end{tabular}

\section{Toelichting maatregel}

Luchtzuiveringstechnieken voor stallen die zijn opgenomen op de Rav-lijst kennen als eis dat zij worden gedimensioneerd op het maximale ventilatie-volume van de stal. Het toepassen van behandeling van een deelstroom met daarnaast een onbehandelde bypass-stroom is tot dusver niet toegestaan uit oogpunt van handhaving. Dit maakt de toepassing van luchtzuivering relatief duur in vleeskuikenstallen met maximale ventilatie-niveaus die slechts een zeer beperkt deel van het jaar voorkomen. Uit berekeningen blijkt dat bij een dimensionering van een wasser afgestemd op 50\% van de maximale ventilatiecapaciteit, slechts $15 \%$ van de ammoniakemissie via de bypass ongezuiverd hoeft te blijven. De huidige verplichte elektronische monitoring van luchtwassers maakt het mogelijk de belasting van de luchtwasser en de volumestroom van het onbehandelde bypass-deel goed vast te leggen. Deelbehandeling van de ventilatielucht is daardoor goed handhaafbaar.

De maatregel bestaat uit:

- $\quad$ het installeren van een chemische/gecombineerde luchtwasser die wordt gedimensioneerd op $50 \%$ van de maximaal benodigde ventilatiecapaciteit, en een bypass voor de overige ventilatielucht. De netto-stalreductie van de ammoniakemissie bedraagt $75 \%$.

Reductie-effect: bij dimensionering van de luchtwasser op 50\% van het maximum-ventilatieniveau wordt $85 \%$ van de totale ammoniakemissie door de wasser geleid. Bij een was rendement van $90 \%$ wordt hierdoor afgerond $75 \%$ van de totale ammoniakemissie gereduceerd. 


\section{Toelichting praktische implementatie}

De maatregel is toepasbaar in alle bestaande vleeskuikenstallen die nog geen luchtzuivering bevatten ((E 5.6, 5.10, 5.11, 5.14 en 5.100). De maatregel kan in bestaande stallen met lengteventilatie worden ingepast. Verwacht wordt dat de maatregel vanaf 2018 effectief kan zijn en implementatie 5-6 jaar zal vergen.

\section{Toelichting kosten}

Investering voor een luchtwasser op 50\% van max. ventilatieniveau vergt investering van $€ 2$ per dierplaats en jaarkosten van $€ 0,60$ per dierplaats. Er zijn 45 miljoen vleeskuikens in Nederland. Stel dat dit nog voor $100 \%$ van de dierplaatsen toegepast moet worden, dan is de investering $€ 2$ maal 45 miljoen kuikens is $€ 90$ miljoen en jaarkosten $€ 27$ miljoen tot 2030 . Tot en met 2020 is dan de helft hiervan.

\subsection{Rundvee}

\subsubsection{Factsheet 4. Verbetering mestschuiven met nieuwe schuiven}

\section{Verbeterd mestschuifmanagement in rundveestallen met roostervloeren met nieuwe mestschuiven \\ Door nieuwe mestschuiven en verbeterd management van schuiven wordt ammoniakemissie van stalvloeren verminderd omdat urine direct wordt afgevoerd en niet als plassen of poeltjes op de roostervloer achterblijft. \\ Deze maatregel is toepasbaar in diercategorie A1.100 en kan in bestaande stallen worden ingebouwd. $\mathrm{Er}$ is nog tijd nodig voor verdere ontwikkeling en testen van verbeterde mestschuiven. Verwacht wordt dat deze vanaf 2019 beschikbaar kunnen zijn. De ammoniakemissie-reductie wordt geschat op $20 \%$.}

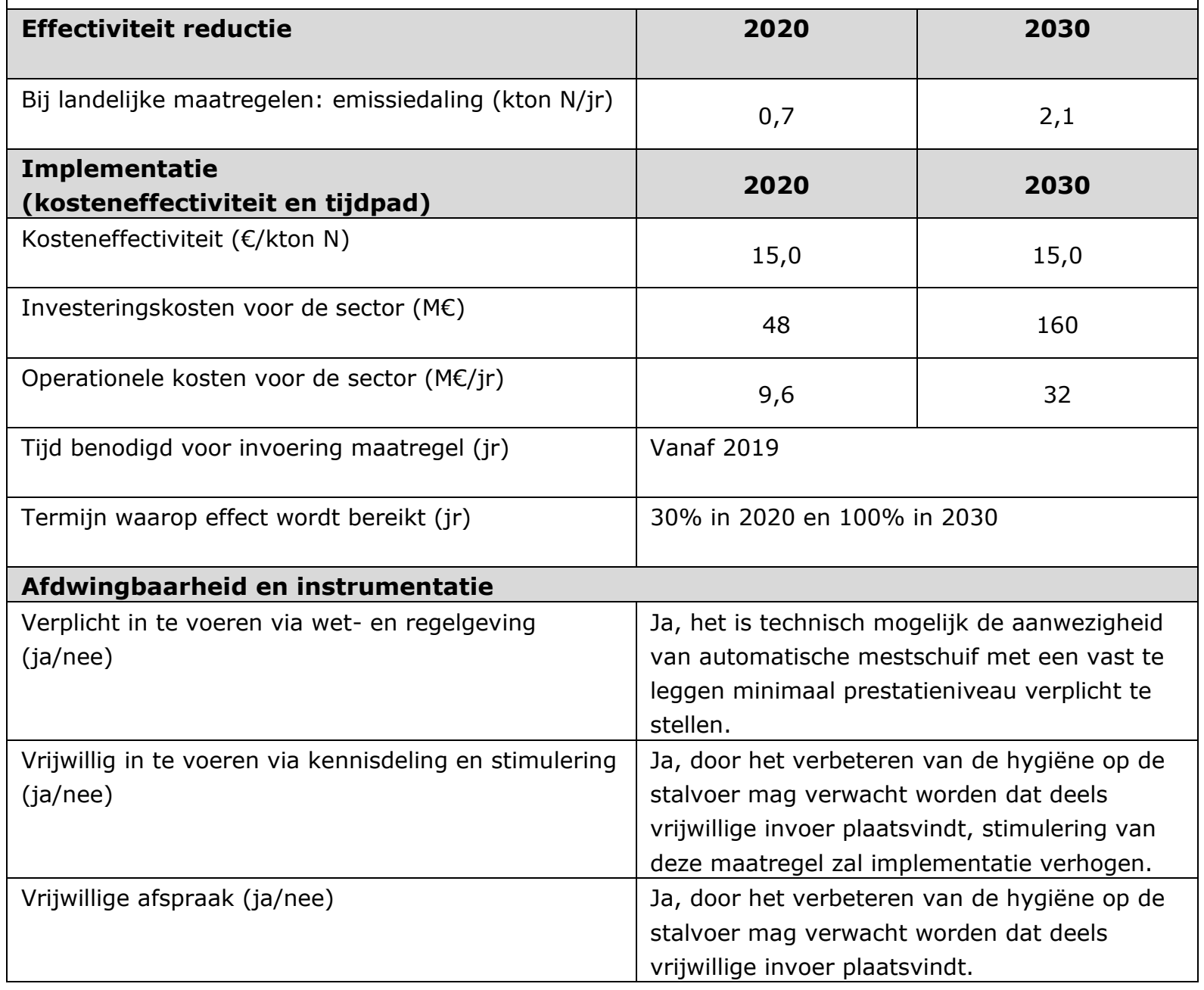




\section{Toelichting maatregel}

Mestresten op stalvloeren belemmeren de afvoer van urine en leiden tot meer plasvorming en daardoor meer emissie. In de praktijk worden roostervloeren met automatische mestschuiven schoongehouden, maar in veel gevallen ook met handmatig schuiven. De schoonmaakprestaties van de huidige aanpak in de praktijk kan verbeterd worden. Hierdoor wordt de hoeveelheid achterblijvende mestresten verminderd, en het volume van achterblijvende urineplassen en de omvang van hieruit emitterend ammoniak teruggedrongen.

De maatregel bestaat uit het installeren van doelmatige mestschuifsystemen waar deze nog niet aanwezig zijn (emissiereductie 20\%)

Bovenstaande reductiepercentages van $20 \%$ op stalbasis is gebaseerd op een verhouding in emissies van de roostervloer ten opzichte van de kelder van 60:40, en op het gegeven dat een derde minder plasvorming plaatsvindt met mestschuif dan bij vloeren zonder mestschuif, en een kwart minder bij vloeren met bestaande mestschuiven (Snoek 2016).

\section{Toelichting praktische implementatie}

De maatregel is toepasbaar in de Rav categorie A1.100, inschatting is dat in 2012-2014 de helft van de A1.100 bedrijven geen mestschuif heeft en de andere helft een mestschuif die moet worden verbeterd/vervangen.

Beschikbaarheid eerste geteste mestschuiven kan vanaf 2019. Invoering zal mede afhangen van productiecapaciteit van de mestschuifleveranciers. Inschatting is dat deze maatregel stapsgewijs tussen 2019 en 2025 in alle A1.100 stallen kan zijn doorgevoerd.

\section{Toelichting kosten}

Aangenomen wordt dat deze verbeterde mestschuiven wat duurder zijn dan de nu gebruikelijke mestschuiven en de investering $€ 100$ per melkkoe bedraagt. Vanwege snelle afschrijving en hoge onderhoudskosten, worden de jaarkosten op $€ 20$ per koe geschat. Er zijn 1,6 miljoen melkkoeien in Nederland. Totale investering sector is dan $€ 160$ miljoen en jaarkosten $€ 32$ miljoen. Als in $202030 \%$ van de bedrijven dit heeft geïmplementeerd, bedraagt de investering $€ 48$ miljoen en de jaarkosten $€ 9,6$ miljoen. 


\subsubsection{Factsheet 5. Bolle rubberen coating roostervloer}

\section{Bolle rubber coating van roostervloer in bestaande stallen}

De bestaande roostervloer wordt voorzien van een rubberen toplaag met een bolle vorm. De emissiereductie wordt bereikt omdat zo min mogelijk urine op de roosters blijft staan.

Deze maatregel is toepasbaar in diercategorie A1.100 en kan in bestaande stallen worden ingebouwd. Deze maatregel heeft nog geen emissiefactor. De reductie wordt (conservatief) geschat op 30\%.

\begin{tabular}{|c|c|c|}
\hline Effectiviteit reductie & 2020 & 2030 \\
\hline Bij landelijke maatregelen: emissiedaling (kton N/jr) & 1,6 & 3,2 \\
\hline $\begin{array}{l}\text { Implementatie } \\
\text { (kosteneffectiviteit en tijdpad) }\end{array}$ & 2020 & 2030 \\
\hline Kosteneffectiviteit ( $\mathrm{m} \ln € /$ kton $\mathrm{N}$ ) & 16,2 & 15,9 \\
\hline Investeringskosten voor de sector ( $\mathrm{mln} €$ ) & 256 & 510 \\
\hline Operationele kosten voor de sector ( $\mathrm{mln} € / \mathrm{jr}$ ) & 26 & 51 \\
\hline Tijd benodigd voor invoering maatregel (jr) & \multicolumn{2}{|c|}{$\begin{array}{l}\text { Inschatting van de implementatie } 50 \% 2020 \text {, } \\
2030100 \%\end{array}$} \\
\hline Termijn waarop effect wordt bereikt (jr) & \multicolumn{2}{|l|}{ Idem } \\
\hline \multicolumn{3}{|l|}{ Afdwingbaarheid en instrumentatie } \\
\hline $\begin{array}{l}\text { Verplicht in te voeren via wet- en regelgeving } \\
\text { (ja/nee) }\end{array}$ & \multicolumn{2}{|c|}{$\begin{array}{l}\text { Ja/nee (als mogelijkheid is in te schatten). } \\
\text { Indien niet verplicht invoering beperkt door } \\
\text { kosten maatregel. Er is momenteel maar één } \\
\text { bedrijf dat kan leveren. }\end{array}$} \\
\hline $\begin{array}{l}\text { Vrijwillig in te voeren via kennisdeling en stimulering } \\
\text { (ja/nee) }\end{array}$ & \multicolumn{2}{|c|}{$\begin{array}{l}\text { Nee, gaat niet gebeuren. Voordeel van de vloer } \\
\text { tov goedkope watertoevoeging is dat het goed } \\
\text { is voor de klauwgezondheid. }\end{array}$} \\
\hline Vrijwillige afspraak (ja/nee) & \multicolumn{2}{|c|}{ Nee, weinig kans. } \\
\hline
\end{tabular}

\section{Toelichting Maatregel}

Deze maatregel is uitvoerbaar in bestaande stallen. De urine loopt meteen van de roosters via de roosterspleten in de mestput en beperkt zo de emissie van de roosters. Ten behoeve van de beloopbaarheid en klauwgezondheid is de toplaag verend. Om te voorkomen dat urine in voegen achterblijft is de oppervlakte glad.

\section{Toelichting praktische implementatie}

$\mathrm{Er}$ is momenteel maar één leverancier, dat zal remmend werken op de snelheid van de implementatie van deze maatregel. Ten tweede wordt het gezien als een dure oplossing. Een voordeel is het gunstige effect op de klauwgezondheid, de reden waarom het in Ierland destijds voor vleesvee is ontwikkeld.

\section{Toelichting kosten}

Per koe wordt gerekend met $4 \mathrm{~m} 2$ roosteroppervlak, de kosten van de coating bedragen $80 €$ per $\mathrm{m}^{2}$. De investering komt daar mee op $€ 320$ per koe. Jaarkosten ca $10 \%$, betekent $€ 32$ per koe.

In Nederland zijn 1,6 miljoen. melkkoeien.

Een implementatie van 50\% in 2020: 50\% *1,6*€32=€25,6 miljoen. In 2030 wordt dat voor $100 \% € 51$ miljoen. 


\subsubsection{Factsheet 6. Ureaseremmers}

\section{Inzet urease-remmers op stalvloer in runderstallen}

De maatregel houdt in dat ureaseremmers op de roostervloer wordt aangebracht waardoor ureum niet/in mindere mate, wordt omgezet in ammoniak.

De maatregel is toepasbaar in de categorieën A1.2 t/m A1.100 en kan in bestaande stallen worden ingebouwd. De toepassing bevindt zich nu nog in een experimentele fase. Markintroductie mag op zijn vroegst verwacht worden vanaf 2020. Kosten urease-remmers zijn in dit stadium moeilijk in te schatten.

\begin{tabular}{|c|c|c|}
\hline Effectiviteit reductie & 2020 & 2030 \\
\hline Bij landelijke maatregelen: emissiedaling (kton N/jr) & - & 3,3 \\
\hline $\begin{array}{l}\text { Implementatie } \\
\text { (kosteneffectiviteit en tijdpad) }\end{array}$ & 2020 & 2030 \\
\hline Kosteneffectiviteit $(€ /$ kton $N)$ & & 5,3 \\
\hline Investeringskosten voor de sector $(M €)$ & - & 80 \\
\hline Operationele kosten voor de sector $(\mathrm{M} € / \mathrm{jr})$ & - & 17,5 \\
\hline Tijd benodigd voor invoering maatregel (jr) & \multicolumn{2}{|l|}{ Vanaf 2020} \\
\hline Termijn waarop effect wordt bereikt (jr) & \multicolumn{2}{|l|}{$2012-2030$} \\
\hline \multicolumn{3}{|l|}{ Afdwingbaarheid en instrumentatie } \\
\hline $\begin{array}{l}\text { Verplicht in te voeren via wet- en regelgeving } \\
\text { (ja/nee) }\end{array}$ & \multicolumn{2}{|c|}{$\begin{array}{l}\text { Ja. Deze emissie-arme maatregel kan in } \\
\text { principe in alle conventionele en emissie-arme } \\
\text { stallen, bestaand en nieuwbouw, verplicht } \\
\text { worden gesteld. }\end{array}$} \\
\hline $\begin{array}{l}\text { Vrijwillig in te voeren via kennisdeling en stimulering } \\
\text { (ja/nee) }\end{array}$ & \multicolumn{2}{|c|}{$\begin{array}{l}\text { Meer stikstof in de mest zou in combinatie met } \\
\text { stimulering tot vrijwillige implementatie } \\
\text { kunnen leiden. }\end{array}$} \\
\hline Vrijwillige afspraak (ja/nee) & \multicolumn{2}{|l|}{ Nee. } \\
\hline
\end{tabular}

\section{Toelichting maatregel}

Ammoniak in urineplassen en mestopslag ontstaat door omzetting van het in de urine aanwezige ureum. Deze omzetting is mogelijk door het enzym urease, dat in ruime mate aanwezig is op stalvloeren. De emissie van stalvloeren kan worden verminderd door de werking van dit enzym te blokkeren. Er bestaat een scala aan stoffen die zich binden aan het urease-enzym en daardoor de omzetting van ureum verhinderen (ureaseremmers). Specifiek voor toepassing in runderstallen dienen deze stoffen veilig voor mens, dier en natuur te zijn. Een Duits bedrijf heeft een ureaseremmer in ontwikkeling (getoetst voor deze toepassing in een voedselproductie-omgeving volgens EU-richtlijnen) die momenteel verder wordt geoptimaliseerd en getest in stallen.

De maatregel bestaat uit:

- $\quad$ het installeren van een automatische sproei-installatie in stallen met roostervloeren (A1.100), die met regelmatige tussenpozen de in vloeistof opgeloste ureaseremmer op de vloer aanbrengt (emissiereductie 30\%).

- $\quad$ het aanbrengen van een automatische sproei-installatie in stallen met emissiearme vloeren (A1.2 t/m A1.29), die met regelmatige tussenpozen de in water opgeloste ureaseremmer op de vloer aanbrengt (emissiereductie 45\%). 
Het reductie\% voor roostervloeren is gebaseerd op de aanname dat de emissieverhouding tussen vloer en kelder 60:40 is en dat ureaseremmers de vloeremissie kunnen halveren (gebaseerd op onderzoek Dairy Campus/Universiteit van Kiel). Voor dichte vloeren komt $90 \%$ van de stalemissie van de vloeren. Een halvering van de vloeremissie betekent dan op stalniveau een reductie van $45 \%$.

\section{Toelichting praktische implementatie}

De techniek is nog in ontwikkeling. De toepassing van ureaseremmers is ook nog niet toegestaan in Nederland. Daar zullen nog procedures voor moeten doorlopen worden. Hier is in Duitsland al wel aan gewerkt. De technische implementatie-snelheid zal afhangen van de beschikbaarheid van de ureaseremmers en de toedieningstechniek. De productiecapaciteit van de leveranciers is hier naar verwachting de remmende factor. Een inschatting is dat deze maatregel stapsgewijs tussen 2019 en 2025 in alle A1.2 t/m A1.100 stallen kan zijn doorgevoerd.

\section{Toelichting kosten}

De investering van de automatische sproei-installatie (robot) wordt geschat op ca. $€ 5.000$. Dit is $€ 50$ per dierplaats. Jaarkosten $20 \%$ van investering, is $€ 10$ per dierplaats. Kosten urease zijn laag, aangenomen wordt $€ 1$ per dierplaats. Op basis van 1,6 miljoen melkkoeien is de investering tot 2030 $€ 80$ miljoen en de jaarkosten $€ 17,5$ miljoen.

\subsubsection{Factsheet 7. Ventilatiemanagement gericht op beperkt debiet}

\section{Ventilatiemanagement gericht op beperkt debiet in melkveestallen}

De maatregel beoogt door het verkleinen van de luchtinlaat het ventilatiedebiet te verlagen en daarmee de luchtsnelheid over het emitterend oppervlak te reduceren. Dit kan worden gerealiseerd met regelbare gordijnen.

Volgens Mosquera et al. (2016) betekent een reductie van de ventilatie in melkveestallen met $25 \%$ een ammoniakemissiereductie van $10 \%$.

\begin{tabular}{|c|c|c|}
\hline Effectiviteit reductie & 2020 & 2030 \\
\hline Bij landelijke maatregelen: emissiedaling (kton N/jr) & 1,1 & \\
\hline $\begin{array}{l}\text { Implementatie } \\
\text { (kosteneffectiviteit en tijdpad) }\end{array}$ & 2020 & 2030 \\
\hline Kosteneffectiviteit (mln $€ /$ kton $N$ ) & 16,8 & \\
\hline Investeringskosten voor de sector ( $\mathrm{mln} . €$ ) & 120 & \\
\hline Operationele kosten voor de sector ( $\mathrm{mln} . € / \mathrm{jr}$ ) & 18 & \\
\hline Tijd benodigd voor invoering maatregel (jr) & $100 \%$ & \\
\hline Termijn waarop effect wordt bereikt (jr) & \multicolumn{2}{|c|}{ Meteen effect na installatie } \\
\hline \multicolumn{3}{|l|}{ Afdwingbaarheid en instrumentatie } \\
\hline $\begin{array}{l}\text { Verplicht in te voeren via wet- en regelgeving } \\
\text { (ja/nee) }\end{array}$ & \multicolumn{2}{|c|}{$\begin{array}{l}\text { Ja, maar dan dient tbv handhaving online } \\
\text { regeling gelogd te worden. }\end{array}$} \\
\hline $\begin{array}{l}\text { Vrijwillig in te voeren via kennisdeling en stimulering } \\
\text { (ja/nee) }\end{array}$ & \multicolumn{2}{|c|}{$\begin{array}{l}\text { Beperkt, gaat tegen trend van laatste jaren in } \\
\text { om stallen steeds meer open te maken. }\end{array}$} \\
\hline Vrijwillige afspraak (ja/nee) & \multicolumn{2}{|l|}{ Zie boven. } \\
\hline
\end{tabular}




\section{Toelichting maatregel}

De lange zijwanden van rundveestallen zijn vaak open en voorzien van gordijnen. Het ventilatiedebiet wordt verkleind door de ventilatieopening kleiner te maken door de gordijnen omhoog te doen (gordijnen sluiten in rundveestallen van onder naar boven). Door de grote variatie in emissie en ventilatie in de praktijk moet de ventilatie minstens $25 \%$ lager zijn dan zonder management van de inlaatopeningen om aantoonbaar ammoniakemissie te reduceren.

\section{Toelichting praktische implementatie}

De laatste jaren is de trend in de melkveehouderij erop gericht de koeien maximaal zichtbaar te maken door de stallen zo open mogelijk te bouwen. Dit past bij de maatschappelijke vraag naar transparantie. Deze maatregel gaat tegen deze trend in.

Om te handhaven wordt aanbevolen een regelsysteem te installeren die tevens de gordijnstanden kan registreren en vastleggen (loggen). De meeste stallen hebben gordijnen, de kosten behelzen dan een mechanische regeling en computergestuurde regelaar. Om weersafhankelijk te kunnen regelen is een weerstation nodig.

Omdat aangenomen wordt dat de boeren al gordijnen hebben kan er van uitgegaan worden dat implementatie op korte termijn mogelijk is en is de aanname dat $100 \%$ in 2020 , op technische gronden, geïmplementeerd kan zijn. Regelsystemen en weerstations zijn vrij algemeen verkrijgbaar en er wordt vanuit gegaan dat de levering van deze producten niet tijds beperkend zal zijn voor de implementatie.

\section{Toelichting kosten}

Uitgaande van een stallengte van 0,5 m per koe, wordt het gordijnoppervlak $1,5 \mathrm{~m}^{2}$ per koe. De investering voor ventilatiesysteem met gordijnen met volautomatische regeling is ca. $€ 100$ per $\mathrm{m}^{2}$ (Bron: Groeien 2013, Investeringsgids voor melkveehouders), wat dus neer komt op $€ 150$ per melkkoe. De jaarkosten zijn dan ca. $€ 20$ per dierplaats. Er wordt aangenomen dat als implementatie afhangt van technische aspecten, 5 jaar nodig is voor volledig implementatie.

Wanneer al gordijnen aanwezig zijn zullen de kosten halveren, dus $€ 75$ per melkkoe met jaarkosten van $€ 11$.

Bij de kostenberekeningen is ervan uitgegaan dat de boeren al gordijnen hebben en dat implementatie dus op korte termijn kan. Er zijn 1,6 miljoen melkkoeien. Dus investering tot 2020 is $€ 120$ miljoen en jaarkosten $€ 18$ miljoen. We gaan ervan uit dat alle boeren al gordijnen hebben. Wanneer ook gordijnen geïnstalleerd moeten worden, verdubbelen de kosten. 


\section{Luchtmixen van mest in de mestkelder}

De uitwisseling van ammoniak tussen de mest en de lucht hangt af van de fysische eigenschappen van de toplaag van de mest. Door volgens een voorgeschreven procedure de mest te mixen wordt de chemie op dit grensvlak van mest en lucht zodanig beïnvloed dat de emissie van ammoniak afneemt.

Hoewel hogere reducties zijn gemeten houden we hier een voorzichtige reductie van $30 \%$ aan voor deze maatregel.

\begin{tabular}{|c|c|c|}
\hline Effectiviteit reductie & 2020 & 2030 \\
\hline Bij landelijke maatregelen: emissiedaling (kton N/jr) & 1,6 & 3,2 \\
\hline $\begin{array}{l}\text { Implementatie } \\
\text { (kosteneffectiviteit en tijdpad) }\end{array}$ & 2020 & 2030 \\
\hline Kosteneffectiviteit (mln. $€ /$ kton $N$ ) & 31,2 & 31,2 \\
\hline Investeringskosten voor de sector ( $\mathrm{mln} . €$ ) & 360 & 720 \\
\hline Operationele kosten voor de sector ( $\mathrm{mln} . € / \mathrm{jr}$ ) & 50 & 100 \\
\hline Tijd benodigd voor invoering maatregel (jr) & \multicolumn{2}{|c|}{$\begin{array}{l}50 \% \text { in } 2020 \text { mogelijk, } 100 \% \text { in } 2030 \\
\text { Remmende factor is de markt, op dit moment } \\
\text { maar één leverancier }\end{array}$} \\
\hline Termijn waarop effect wordt bereikt (jr) & \multicolumn{2}{|c|}{ Idem } \\
\hline \multicolumn{3}{|l|}{ Afdwingbaarheid en instrumentatie } \\
\hline $\begin{array}{l}\text { Verplicht in te voeren via wet- en regelgeving } \\
\text { (ja/nee) }\end{array}$ & \multicolumn{2}{|c|}{$\begin{array}{l}\text { Technisch mogelijk, wel combineren met logger } \\
\text { zodat werking gecontroleerd kan worden. }\end{array}$} \\
\hline $\begin{array}{l}\text { Vrijwillig in te voeren via kennisdeling en stimulering } \\
\text { (ja/nee) }\end{array}$ & \multicolumn{2}{|c|}{ Ja, als extra kosten gesubsidieerd worden. } \\
\hline Vrijwillige afspraak (ja/nee) & \multicolumn{2}{|c|}{$\begin{array}{l}\text { Wellicht bespreekbaar, argument voor mixen is } \\
\text { de hypothese dat als je dat frequent doet, de } \\
\text { gasvormige emissie-concentraties van } \\
\text { gevaarlijke anaerobe mestgassen lager en dus } \\
\text { minder schadelijk is. }\end{array}$} \\
\hline
\end{tabular}

\section{Toelichting maatregel}

De kelderemissie vermindert door het vermijden van laagvorming in de mest met verschillende samenstelling. Dit wordt bereikt door frequent mengen van de opgeslagen mest met luchttoevoer. Hierdoor veranderen de chemische evenwichten van de fysische processen die leiden tot de vervluchtiging van ammoniak op het grensvlak van mest en lucht.

Wanneer rundveemest in de kelder staat, ontstaat een drijflaag op de mest. Dit werkt als een korst die fungeert als een soort schijnvloer waar plasvorming op plaats vindt. Plasvorming heeft een verhogend effect op de ammoniakemissie. Frequent mixen voorkomt de korst- en plasvorming waardoor de emissie beperkt kan worden. Een mogelijk meespelend effect is de lagere $\mathrm{pH}$ van de bovenlaag door het mengen van de mest. Het is bekend dat de $\mathrm{pH}$ van de bovenste laag van de mest hoger is dan die van de lagen eronder. Een hoge $\mathrm{pH}$ verhoogt de ammoniakemissie. Dat effect is op dit moment echter alleen theoretisch onderbouwd, maar moet nog gevalideerd worden. Het mixen dient te gebeuren volgens een voorgeschreven procedure. Wanneer door menging teveel zuurstof in de mest gebracht wordt zal namelijk een afwenteling naar het broeikasgas lachgas $\left(\mathrm{N}_{2} \mathrm{O}\right)$ kunnen ontstaan. 
Boeren hebben al een pompinstallatie, maar deze dient om de mest rond te pompen zodat de korst kapot gaat, wat nodig is om de mestput te legen. Deze pompinstallatie leent zich niet voor de manier van frequent mixen zoals deze maatregel vereist.

Dit frequente mixen (met een zgn. roostermixer) veroorzaakt veel minder mestbeweging, -beroering en menging dan het reguliere mixen volgens het systeem van rondpompen.

Frequent rondpompen met de pomp die de boeren reeds hebben zou een optie kunnen zijn, maar of deze manier van mixen werkt, is niet bekend. Op het moment wordt daar onderzoek naar gedaan. Deze optie is niet in de factsheet meegenomen.

In een oriënterend onderzoek is 40 en $50 \%$ reductie gemeten, maar nadere validatie loopt op dit moment. Eind 2017 worden de resultaten verwacht. Hier rekenen we voorzichtigheidshalve $30 \%$ reductie in voor deze maatregel.

Wanneer lucht ingebracht wordt bestaat, zoals gezegd, het risico op $\mathrm{N}_{2} \mathrm{O}$ productie omdat nitrificatie op kan treden. Dit is in de oriënterende metingen meegenomen en het mixen lijkt geen effect te hebben op de $\mathrm{N}_{2} \mathrm{O}$ productie. Blijkbaar zijn er nog andere limiterende factoren die nitrificatie voorkomen.

\section{Toelichting kosten}

De installatie (Aeromix) vergt een investering van ca. $€ 40.000$ per bedrijf (100 melkkoeien). Er zijn ca. 18.000 bedrijven in Nederland. Totaal investering wordt dan $€ 720$ miljoen tot 2030. Jaarkosten worden berekend als $15 \%$ van de investeringskosten, en is daarmee $€ 100$ miljoen.

Wanneer jongvee wordt meegenomen in de berekeningen kan respectievelijk 2,1 en 4,3 kton $\mathrm{NH}_{3}-\mathrm{N}$ bespaard worden. Wanneer daar geen extra investeringen voor hoeven worden gedaan daalt de prijs met $25 \%$ tot ca $23 €$ per $\mathrm{kg} \mathrm{NH} 3-\mathrm{N}$. 


\subsubsection{Factsheet 9. Luchtzuivering in de nok}

\section{Inpassing luchtzuivering in runderstallen via nok-ventilatie}

De maatregel voorziet in het plaatsen van mechanische ventilatie en een luchtwasser. Om het open karakter van de stal te handhaven hoeft niet alle lucht via de nok te worden afgevoerd en gereinigd.

Luchtzuivering via de nok kan het best ingepast worden in nieuwbouwstallen die bestaande conventionele huisvesting (A1.100) vervangen.

Wanneer het aandeel ongezuiverde lucht beperkt blijft tot $25 \%$ kan de ammoniakemissie-reductie door deze maatregel $65 \%$ bedragen.

\begin{tabular}{|l|c|c|}
\hline Effectiviteit reductie & $\mathbf{2 0 2 0}$ & $\mathbf{2 0 3 0}$ \\
\hline Bij landelijke maatregelen: emissiedaling (kton N/jr) & 0,5 & 3,1 \\
\hline $\begin{array}{l}\text { Implementatie } \\
\text { (kosteneffectiviteit en tijdpad) }\end{array}$ & $\mathbf{2 0 2 0}$ & $\mathbf{2 0 3 0}$ \\
\hline Kosteneffectiviteit (M€/kton N) & 34,6 & 34,6 \\
\hline Investeringskosten voor de sector (M€) & \multicolumn{1}{|c|}{18} \\
\hline Operationele kosten voor de sector (M€/jr) & $\begin{array}{l}\text { Luchtzuivering via nok met automatische } \\
\text { inlaat-sturing: vanaf 2019 }\end{array}$ \\
\hline Tijd benodigd voor invoering maatregel (jr) & $8 \%$ in 2020 en 48\% in 2030 \\
\hline $\begin{array}{l}\text { Termijn waarop effect wordt bereikt (jr) } \\
\text { Afdwingbaarheid en instrumentatie }\end{array}$ & Ja, is geschikt als te kiezen Rav-maatregel. \\
\hline $\begin{array}{l}\text { Verplicht in te voeren via wet- en regelgeving } \\
\text { (ja/nee) }\end{array}$ & $\begin{array}{l}\text { Ja, stimulering kan het implementatieniveau } \\
\text { verhogen. } \\
\text { (jajwillig in te voeren via kennisdeling en stimulering }\end{array}$ \\
\hline $\begin{array}{l}\text { Vrijwillige afspraak (ja/nee) } \\
\text { Nee. }\end{array}$ \\
\hline
\end{tabular}

\section{Toelichting maatregel}

De stallucht in melkveestallen wordt in de praktijk met een natuurlijk ventilatiesysteem ververst. De stallen zijn uitgerust met grote inlaatvlakken aan weerzijden van de stal en een open nok waardoor de lucht wordt afgevoerd. Deze stallen hebben hierdoor een open karakter. Natuurlijke ventilatie is niet geschikt voor toepassing van luchtzuiveringstechnieken. Om deze technieken te kunnen benutten is een mechanisch ventilatiesysteem nodig. Dergelijke ventilatiesystemen kunnen echter het open karakter van stallen verstoren. Om enerzijds het hoge verwijderingsrendement van luchtwassers te kunnen benutten en anderzijds het gewenste open karakter van melkveestallen dient de uitvoering en regeling van het ventilatiesysteem op deze eisen te worden aangepast.

De maatregel bestaat uit:

- Het aanbrengen van een mechanisch ventilatiesysteem met grote regelbare inlaatopeningen aan weerszijden van de stal, die het open karakter van de stal intact laat. In de nok van de stal worden ventilatoren opgenomen die de stallucht afvoeren naar een luchtwasser.

- De regelbare inlaatopeningen aan weerzijden van de stal worden afzonderlijk automatisch aangestuurd, waarbij afhankelijk van windrichting en snelheid één zijde zoveel mogelijk open blijft en de ander zoveel als nodig gesloten. Op deze wijze wordt dwarsventilatie van ongezuiverde stallucht beperkt tot ca. $25 \%$ van het totale ventilatievolume. 
Aangestuurde inlaatopeningen leiden tot een behandelbare luchtstroom die $75 \%$ van het totale ventilatievolume bedraagt. Uitgaande van het verwijderingsrendement van een chemische wasser van $90 \%$, bedraagt de reductie van de stalemissie $75 \times 0.90=$ afgerond $65 \%$.

\section{Toelichting praktische implementatie}

Implementatie vanuit technisch oogpunt, uitgaande van de verplichting van de maatregel voor alle stallen met Rav-code A1.100 zal kunnen starten vanaf 2019, afhankelijk van de beschikbaarheid van op rundveestallen toegeruste luchtwassers en ventilatieregelingen.

Deze maatregel kan het best ingepast worden in nieuwbouwstallen die bestaande conventionele huisvesting (A1.100) vervangen. Implementatie in de praktijk hangt daarmee af van het vervangingsritme van stallen. Voor nieuwbouw van rundveestallen wordt overigens de kanttekening geplaatst dat door uitgestelde investeringen in de rundveestallen het afgelopen decennium en de afschaffing van het melkquotum, de laatste paar jaar heel veel nieuwbouw heeft plaatsgevonden. Het bestand aan stallen is echter dermate oud, dat we de gemiddelde investeringssnelheid van $4 \%$ voor nieuwe stallen handhaven. Bij volledige implementatie zal het effect op de emissie 6,5 kton $\mathrm{NH}_{3}-\mathrm{N}$ bedragen, bij een fasering van 4\% per jaar zal de reductie tot 2020 en 2030 respectievelijk $8 \%$ en $48 \%$ van deze waarde zijn.

\section{Toelichting kosten}

De investering bedraagt $€ 450$ per melkkoe. De jaarkosten voor rente, afschrijving en onderhoud bedragen $€ 60$ per koe en de exploitatiekosten (hoofdzakelijk energie) bedragen $€ 80$ per koe. Totale jaarkosten dus $€ 140$ per melkkoe. Er zijn 1,6 miljoen melkkoeien in Nederland. Als 4\% per jaar een nieuwe stal bouwt, dan is de jaarlijkse investering 4\%*1,6 miljoen *€ $450=€ 29$ miljoen. Tot 2020 een investering van $2 * 29=€ 58$ miljoen. Jaarkosten zijn $4 \% * 1,6$ miljoen $* € 140=€ 9$ miljoen. In 2020 (dus voor de jaren 2019 en 2020) jaarkosten van $2 * 9=€ 18$ miljoen. In 2030 is dat respectievelijk $12 * 29=€ 346$ miljoen en $12 * 9=€ 108$ miljoen.

\subsubsection{Factsheet 10. Luchtzuivering van lucht uit de kelder}

\begin{tabular}{|c|c|c|}
\hline \multicolumn{3}{|c|}{ 10. Inpassing luchtzuivering in runderstallen via kelder-ventilatie } \\
\hline Effectiviteit reductie & 2020 & 2030 \\
\hline Bij landelijke maatregelen: emissiedaling (kton $\mathrm{N} / \mathrm{jr}$ ) & 0,2 & 1,2 \\
\hline $\begin{array}{l}\text { Implementatie } \\
\text { (kosteneffectiviteit en tijdpad) }\end{array}$ & 2020 & 2030 \\
\hline Kosteneffectiviteit (M€/kton $\mathrm{N}$ ) & 41,6 & 41,6 \\
\hline Investeringskosten voor de sector (M€) & 34 & 204 \\
\hline Operationele kosten voor de sector (M€/jr) & 8,4 & 50,4 \\
\hline Tijd benodigd voor invoering maatregel (jr) & \multicolumn{2}{|c|}{$\begin{array}{l}\text { Luchtzuivering via kelder met automatische } \\
\text { inlaat-sturing: vanaf } 2019 .\end{array}$} \\
\hline Termijn waarop effect wordt bereikt (jr) & \multicolumn{2}{|l|}{$2019-2030$} \\
\hline \multicolumn{3}{|l|}{ Afdwingbaarheid en instrumentatie } \\
\hline $\begin{array}{l}\text { Verplicht in te voeren via wet- en regelgeving } \\
\text { (ja/nee) }\end{array}$ & \multicolumn{2}{|c|}{ Ja, is geschikt als te kiezen Rav-maatregel. } \\
\hline $\begin{array}{l}\text { Vrijwillig in te voeren via kennisdeling en stimulering } \\
\text { (ja/nee) }\end{array}$ & \multicolumn{2}{|c|}{$\begin{array}{l}\text { Ja, stimulering kan het implementatieniveau } \\
\text { verhogen. }\end{array}$} \\
\hline Vrijwillige afspraak (ja/nee) & \multicolumn{2}{|c|}{ Nee. } \\
\hline
\end{tabular}




\section{Toelichting maatregel}

De stallucht in melkveestallen wordt in de praktijk met een natuurlijk ventilatiesysteem ververst. Natuurlijke ventilatie is niet geschikt voor toepassing van luchtzuiveringstechnieken. Om deze technieken te kunnen benutten is een mechanisch ventilatiesysteem nodig. Om enerzijds het hoge verwijderingsrendement van luchtwassers te kunnen benutten en anderzijds het gewenste open karakter van melkveestallen, dient de uitvoering en regeling van het ventilatiesysteem op deze eisen te worden aangepast. Dit kan bereikt worden door een combinatie van natuurlijke en mechanische ventilatie toe te passen. Zo is het mogelijk de lucht in de kelderopslag onder de roosters afzonderlijk mechanisch af te voeren en te zuiveren, terwijl de stal natuurlijk geventileerd blijft.

\section{De maatregel bestaat uit:}

- Het aanbrengen van een afzuigsysteem onder de roosters om de lucht in de mestkelders separaat af te voeren en te behandelen. De stallucht boven de roosters wordt via natuurlijke ventilatie ververst. Door het afzuigsysteem wordt uitwisseling van kelderlucht met de stal tegengegaan.

- Het plaatsen van een luchtwasser die de mechanische geventileerde kelderlucht zuivert. Hierdoor wordt het merendeel van het aandeel van de kelderemissie in de totale stalemissie teruggedrongen. Gerekend over de volledige stalemissie bedraagt de reductie $25 \%$.

Bij het berekenen van het reductiepercentage bij stallen met roostervloeren (A1.100) is er van uitgegaan dat de verhouding 'vloeremissie : kelderemissie' 60:40 is. Tevens is de aanname dat effectief $80 \%$ van de kelderlucht wordt afgezogen. Deze wordt gezuiverd met een chemische luchtwasser met een verwijderings-rendement van 90\%. Dit leidt tot een netto emissiereductie op stal basis van $40 \times 0.75 \times 0.90=$ afgerond $25 \%$ op stalbasis.

\section{Toelichting praktische implementatie}

Implementatie vanuit technisch oogpunt, uitgaande van de verplichting van de maatregel voor alle stallen met Rav-code A1.100 zal kunnen starten vanaf 2019, afhankelijk van de beschikbaarheid van op rundveestallen toegeruste luchtwassers en ventilatieregelingen.

Deze maatregel kan het best ingepast worden in nieuwbouwstallen die bestaande conventionele huisvesting (A1.100) vervangen. Implementatie in de praktijk hangt daarmee af van het vervangingsritme van stallen. Voor nieuwbouw van rundveestallen wordt overigens de kanttekening geplaatst dat door uitgestelde investeringen in de rundveestallen het afgelopen decennium en de afschaffing van het melkquotum, de laatste paar jaar heel veel nieuwbouw heeft plaatsgevonden. Het bestand aan stallen is echter dermate oud, dat we de gemiddelde investeringssnelheid van $4 \%$ voor nieuwe stallen handhaven. Bij volledige implementatie zal het effect op de emissie 2,5 kton $\mathrm{NH}_{3}-\mathrm{N}$ bedragen, bij een fasering van 4\% per jaar zal de reductie tot 2020 en 2030 respectievelijk $8 \%$ en $48 \%$ van deze waarde zijn.

\section{Toelichting kosten}

De investering bedraagt $€ 266$ per melkkoe. De jaarkosten voor rente, afschrijving en onderhoud bedragen $€ 34$ per koe en de exploitatiekosten (hoofdzakelijk energie) bedragen $€ 32$ per koe. Totale jaarkosten dus $€ 66$ per melkkoe. Er zijn 1,6 miljoen melkkoeien in Nederland. Als $4 \%$ per jaar een nieuwe stal bouwt, dan is de jaarlijkse investering 4\%*1,6 miljoen * $€ 266=€ 17$ miljoen. Tot 2020 een investering van $2 * 17=€ 34$ miljoen. Jaarkosten zijn 4\%*1,6 miljoen $* € 66=€ 4,2$ miljoen. Tot 2020 jaarkosten van $2 * 4,2=€ 8,4$ miljoen.

Tot 2030 is dat respectievelijk $12 * 17=€ 204$ miljoen en $12 * 4,2=€ 50,4$ miljoen. 


\section{$4 \quad$ Voermaatregelen}

De voermaatregelen zijn gebaseerd op de technische mogelijkheden. Daarmee is de vraag of boeren bereid zijn op het scherpst van de snede te voeren niet beantwoord. Wanneer voermaatregelen perspectiefvol blijken zal in nadere uitwerking gekeken moeten worden naar bedrijfsmatige optimalisatie. De voermaatregelen zijn uit te voeren op verschillende niveaus (bijvoorbeeld reductie van ruw eiwit in het voer met $10 \mathrm{~g} / \mathrm{kg}$, dan wel $20 \mathrm{~g} / \mathrm{kg}$ ). Elk niveau kun je beschouwen als een aparte maatregel. Vanwege de leesbaarheid is er voor gekozen om het als één maatregel op te nemen in de factsheets met een onderscheid in de niveaus als tijdsgebonden implementatie. Het eerste niveau is dan op korte termijn realiseerbaar (2020), het tweede niveau in 2030. In de synthesetabel in hoofdstuk 6 hebben beide niveaus wel een aparte regel en zijn genummerd als a (eerste niveau, bereikbaar in 2020) en b maatregel (tweede niveau, bereikbaar in 2030) van de betreffende factsheets.

\subsection{Pluimvee}

Vanwege de impact van de maatregelen op de ammoniakemissie en de investeringen zijn in de pluimveehouderij op basis van aantallen dieren, de effecten berekend voor leghennen en vleeskuikens. Sommige maatregelen zijn echter ook uitvoerbaar bij andere pluimveecategorieën.

In Nederland vindt in de vleeskuikenhouderij een overschakeling plaats van snelgroeiende (conventioneel) naar langzamer groeiende kuikens plaats (de zgn. concept kuikens welke in de Nederlandse supermarkten liggen). Een schatting is dat op dit moment ca. $30 \%$ van de bedrijven concept kuikens houdt (dit aandeel zal nog iets toenemen maar niet veel, tenzij er ook een markt hiervoor in het buitenland komt). Van deze kuikens is v.w.b. emissie (ammoniak, geur en fijnstof) niets bekend. Feit is dat de productie met deze kuikens veel minder efficiënt is (langere aanhouding, hoger voerconversie). Een theoretische analyse geeft aan dat de verwachting is dat de emissies per jaar per dierplaats lager zullen zijn dan die van sneller groeiende kuikens, maar per kg gewicht (vleesproductie) hoger (Ellen en Ogink, 2015). Vanwege gebrek aan data kunnen geen berekeningen worden gemaakt voor de langzaam groeiende concept-kuikens. Onderstaande factsheets gaan daarom alleen uit van de conventionele snel groeiende kuikens.

Over het algemeen kan gesteld worden dat de kosten van voermaatregelen voor pluimvee stijgen doordat er meer vrije aminozuren nodig zijn als het eiwitgehalte in het voer daalt om de behoefte van het dier aan essentiële aminozuren te dekken. Hoe meer het daalt, hoe meer vrije aminozuren dienen te worden toegevoegd en des te duurder het voer wordt.

Uit recente (nog niet gepubliceerde) inzichten in de emissies bij pluimvee, voor zover gehouden op strooisel blijkt, dat wanneer het strooisel rul en droog is, het voereffect aantoonbaar is. Echter wanneer het strooisel iets natter is, en de bovenkant 'dichtslaat', is de emissie daardoor lager, en kan een voereffect niet meer worden waargenomen (Aarnink en van de Harn, mondelinge mededeling). Daarom zijn de factsheets 11-14 wel opgenomen, maar het effect is in de praktijk niet gegarandeerd. 


\subsubsection{Factsheet 11. Eiwitgift op maat met hele tarwekorrel voor vleeskuikens}

\section{Eiwitgift op maat met bijvoeren van hele tarwekorrel (vleeskuikens)}

De maatregel beoogt door het toevoegen van de hele tarwekorrel aan het voer een betere afstemming te bereiken tussen de behoefte en het aanbod van eiwit en aminozuren, waardoor de uitscheiding van urinezuur vermindert en daarmee het risico op de vorming van ammoniak.

Wanneer dit resulteert in een afname van het ruw eiwitgehalte in het voer van $10 \mathrm{~g} / \mathrm{kg}$ zal de ammoniakemissie uit de stal met $10 \%$ afnemen.

\begin{tabular}{|c|c|c|}
\hline \multicolumn{3}{|l|}{ Tijdpad } \\
\hline Effectiviteit reductie & 2020 & 2030 \\
\hline $\begin{array}{l}\text { Bij landelijke maatregelen: emissiedaling (kton } \\
\mathrm{N} / \mathrm{jr} \text { ) }\end{array}$ & 0,2 & - \\
\hline $\begin{array}{l}\text { Implementatie } \\
\text { (kosteneffectiviteit en tijdpad) }\end{array}$ & 2020 & 2030 \\
\hline Kosteneffectiviteit (M€/kton N) & 1,7 & - \\
\hline Investeringskosten voor de sector $(M €)$ & 4,2 & - \\
\hline Operationele kosten voor de sector (M€/jr) & 0,4 & - \\
\hline Tijd benodigd voor invoering maatregel (jr) & \multicolumn{2}{|c|}{ Directe invoering van maatregel is mogelijk. } \\
\hline Termijn waarop effect wordt bereikt (jr) & \multicolumn{2}{|c|}{$\begin{array}{l}\text { Invoering van maatregel resulteert direct in } \\
\text { effect. }\end{array}$} \\
\hline \multicolumn{3}{|l|}{ Afdwingbaarheid en instrumentatie } \\
\hline $\begin{array}{l}\text { Verplicht in te voeren via wet- en regelgeving } \\
(\mathrm{ja} / \mathrm{nee})\end{array}$ & \multicolumn{2}{|c|}{$\begin{array}{l}\text { Ja, is geschikt als reducerende voermaatregel en } \\
\text { zou kunnen worden opgenomen in bijlage } 2 \text { van de } \\
\text { Rav. }\end{array}$} \\
\hline $\begin{array}{l}\text { Vrijwillig in te voeren via kennisdeling en } \\
\text { stimulering (ja/nee) }\end{array}$ & \multicolumn{2}{|c|}{$\begin{array}{l}\text { Ja, in combinatie met stimulering is vrijwillige } \\
\text { implementatie te verwachten. }\end{array}$} \\
\hline Vrijwillige afspraak (ja/nee) & \multicolumn{2}{|c|}{ Ja, maatregel wordt al op kleine schaal toegepast. } \\
\hline
\end{tabular}

\section{Toelichting maatregel}

Door de behoefte en aanbod van eiwit en aminozuren beter af te stemmen op de groeicurve van het kuiken, is de uitscheiding van urinezuur te verminderen en daardoor het risico op vorming van ammoniak. Door vleeskuikenvoer op te mengen met een bepaalde hoeveelheid hele tarwe (tarwe heeft een lager ruw eiwitgehalte dan mengvoer) is een betere afstemming te bereiken. De hoeveelheid bij te voeren hele tarwe is afhankelijk van de leeftijd van het kuiken en het eiwitgehalte van het geleverde mengvoer. Een verdere reductie tot een RE-gehalte van $-20 \mathrm{~g} / \mathrm{kg}$ zou theoretisch mogelijk kunnen zijn, maar door het risico op een verslechtering van de groei is dat geen maatregel die nader onderzocht dient te worden. Onderstaande tabel geeft de richtlijnen van het totaal aan ruw eiwit in het voer (mengvoer + hele tarwe) per leeftijdsfase (De referentiewaarde is het eiwitniveau waar men heen moet om de onderstaande reducties te realiseren). 
Tabel 1. Richtlijn voor eiwitgehalte en energiewaarde van het voer per week voor vleeskuikens

\begin{tabular}{ccc}
\hline Week & Referentiewarde eiwit $(\mathrm{g} / \mathrm{kg})$ & Referentiewaarde energie $\left(\mathrm{OE} \mathrm{vlk}_{,} \mathrm{MJ} / \mathrm{kg}\right)$ \\
\hline 1 & 212 & $11,9-12,1$ \\
2 & 200 & \\
3 & 187 & $12,4-12,6$ \\
4 & 180 & \\
5 & 172 & $12,6-12,8$ \\
7 & 167 & \\
\hline
\end{tabular}

\section{Toelichting praktische implementatie}

De maatregel wordt al op beperkte schaal toegepast. Wanneer de vleeskuikenhouder doordrongen is van de voordelen zal hij mogelijk eerder deze maatregel gaan gebruiken. Punt is wel dat vleeskuikenhouders huiverig staan tegenover het verlagen van het ruw eiwitgehalte van het voer, aangezien dit het risico vergroot dat productieresultaten verslechteren en dus het bedrijfsinkomen. Dit kan een grootschalige introductie tegenwerken/remmen.

\section{Toelichting kosten}

Het bijvoeren van hele tarwe leidt weliswaar tot een verlaging van de voerkosten, maar ook de technische resultaten (groei en voederconversie) verslechteren. Uiteindelijk zal het resultaat vergelijkbaar zijn (Van Harn en Veldkamp, 2006). Wel extra investeringen nodig voor een voersilo. Dit is een investering van $€ 7.000$ per bedrijf, voor de ca. 600 bedrijven in Nederland komt dit neer op $€ 4,2$ miljoen. 


\subsubsection{Factsheet 12. Verfijning van fasevoedering bij vleeskuikens}

\section{Verfijning fasenvoeding (vleeskuikens)}

De maatregel beoogt met verbeterde fasenvoeding ( 6 fasen in plaats van 4 ) de eiwitgift beter af te stemmen op de eiwitbehoefte van het dier, waardoor de uitscheiding van urinezuur vermindert en daarmee het risico op de vorming van ammoniak.

Wanneer dit resulteert in een afname van het ruw eiwitgehalte in het voer van $10 \mathrm{~g} / \mathrm{kg}$ zal de ammoniakemissie uit de stal met $10 \%$ afnemen, bij een afname van $20 \mathrm{~g} / \mathrm{kg}$ ruw eiwit zal de emissiereductie $20 \%$ zijn.

\begin{tabular}{|c|c|c|}
\hline \multicolumn{3}{|l|}{ Tijdpad } \\
\hline Effectiviteit reductie & 2020 & 2030 \\
\hline & $\mathrm{RE}=-10 \mathrm{~g} / \mathrm{kg}$ voer & $\mathrm{RE}=-20 \mathrm{~g} / \mathrm{kg}$ voer \\
\hline Bij landelijke maatregelen: emissiedaling (kton N/jr) & 0,2 & 0,5 \\
\hline $\begin{array}{l}\text { Implementatie } \\
\text { (kosteneffectiviteit en tijdpad) }\end{array}$ & 2020 & 2030 \\
\hline Kosteneffectiviteit (M€/kton $\mathrm{N}$ ) & 3,4 & 58 \\
\hline Investeringskosten voor de sector (M€) & 8,4 & 8,4 \\
\hline Operationele kosten voor de sector (M€/jr) & 0,8 & 27,8 \\
\hline Tijd benodigd voor invoering maatregel (jr) & \multicolumn{2}{|c|}{$\begin{array}{l}\text { Directe invoering van de maatregel }-10 \mathrm{~g} / \mathrm{kg} \text { is } \\
\text { technisch mogelijk. In } 2030 \mathrm{kan}-20 \mathrm{~g} / \mathrm{kg} \text { als } \\
\text { vrije aminozuren beschikbaar komen. }\end{array}$} \\
\hline Termijn waarop effect wordt bereikt (jr) & \multicolumn{2}{|c|}{$\begin{array}{l}\text { Invoering van maatregel resulteert direct in } \\
\text { effect. }\end{array}$} \\
\hline \multicolumn{3}{|l|}{ Afdwingbaarheid en instrumentatie } \\
\hline $\begin{array}{l}\text { Verplicht in te voeren via wet- en regelgeving } \\
(\mathrm{ja} / \mathrm{nee})\end{array}$ & \multicolumn{2}{|c|}{$\begin{array}{l}\text { Ja, is geschikt als reducerende voermaatregel, } \\
\text { en zou kunnen worden opgenomen in bijlage } 2 \\
\text { van de Rav. }\end{array}$} \\
\hline $\begin{array}{l}\text { Vrijwillig in te voeren via kennisdeling en stimulering } \\
\text { (ja/nee) }\end{array}$ & \multicolumn{2}{|c|}{$\begin{array}{l}\text { Ja, in combinatie met stimulering is vrijwillige } \\
\text { implementatie te verwachten. }\end{array}$} \\
\hline Vrijwillige afspraak (ja/nee) & \multicolumn{2}{|c|}{ Ja/nee. } \\
\hline
\end{tabular}

\section{Toelichting maatregel}

Via fasen voeding is het mogelijk de eiwitgift af te stemmen op de eiwitbehoefte op de leeftijd / productiestadium van het dier. Dit resulteert in een verminderde uitscheiding van urinezuur en hierdoor een verminderd risico op de vorming van ammoniak.

De maatregel betreft het toepassen van een 6 fasen voer i.p.v. een 4 fasen voer. Naar verwachting kan hier een stalemissiereductie van $10 \%$ bereikt worden in eerste instantie. In tweede instantie, wanneer meer aminozuren beschikbaar komen kan dat oplopen tot 20\% in 2030. De gehalten in Tabel 2 veranderen dan navenant (niet opgenomen in de tabel). 
Tabel 2. Eiwitgift bij 4 fasen voeding (huidig regime) en bij 6 fasen voeding, resulterend in $10 \%$ reductie van ammoniakemissie

\begin{tabular}{lcc}
\hline & Leeftijd (dgn) & Eiwitgehale in voer $(\mathbf{g} / \mathbf{k g})$ \\
\hline 4 fasen & $0-10$ & 215 \\
(huidig) & $10-17$ & 210 \\
& $17-28$ & 205 \\
& $28-$ afleveren & 200 \\
\hline fasen & $0-8$ & 215 \\
(maatregel) & $8-15$ & 210 \\
& $15-22$ & 205 \\
& $22-29$ & 200 \\
& $29-36$ & 195 \\
& $36-$ afleveren & 190 \\
\hline
\end{tabular}

\section{Toelichting praktische implementatie}

De medewerking van mengvoederfabrikant is noodzakelijk, daarnaast dient het primaire bedrijf over voldoende opslagcapaciteit voor het voer te beschikken. De maatregel kan wellicht leiden tot meer transport bewegingen.

\section{Toelichting kosten}

Volgens Veldkamp et al. (2012) hoeft verfijnde fase voedering niet te leiden tot meerkosten, behalve extra investeringen voor voersilo's. Er wordt gerekend met 2 extra silo's per bedrijf. Dat betekent een investering van $€ 14.000$ per bedrijf, voor ca. 600 bedrijven in NL komt dat in totaal op $€ 8,4$ miljoen. Voor een verdere reductie van het eiwit met $20 \mathrm{~g} / \mathrm{kg}$ in 2030 wordt het voer door toevoeging van vrije aminozuren duurder. Een toename van $7 \%$ betekent $€ 0,08$ per kuiken. In Nederland werden gemiddeld 45 miljoen vleeskuikens gehouden (2012-2014, Bron CBS). Er worden ca. 7,5 rondes per jaar behaald, waardoor op jaarbasis 340 miljoen kuikens worden afgeleverd. De totale jaarkosten bedragen daarmee $€ 27$ miljoen. 


\subsubsection{Factsheet 13. Verlagen ruw eiwitgehalte vleeskuikens}

\section{Verlagen van het ruw eiwitgehalte van het voer (vleeskuikens)}

De maatregel verlaagt de eiwitgift waardoor de uitscheiding van urinezuur vermindert en daarmee het risico op de vorming van ammoniak.

Wanneer dit resulteert in een afname van het ruw eiwitgehalte in het voer van $20 \mathrm{~g} / \mathrm{kg}$ zal de ammoniakemissie uit de stal met $20 \%$ afnemen, bij een afname van $30 \mathrm{~g} / \mathrm{kg}$ ruw eiwit zal de emissiereductie $30 \%$ zijn.

\begin{tabular}{|c|c|c|}
\hline Tijdpad & & \\
\hline Effectiviteit reductie & 2020 & 2030 \\
\hline & $R E=-20 \mathrm{~g} / \mathrm{kg}$ voer & $R E=-30 \mathrm{~g} / \mathrm{kg}$ voer \\
\hline Bij landelijke maatregelen: emissiedaling (kton N/jr) & 0,8 & 1,2 \\
\hline $\begin{array}{l}\text { Implementatie } \\
\text { (kosteneffectiviteit en tijdpad) }\end{array}$ & 2020 & 2030 \\
\hline Kosteneffectiviteit (M€/kton $\mathrm{N}$ ) & 35 & 32 \\
\hline Investeringskosten voor de sector $(M €)$ & - & - \\
\hline Operationele kosten voor de sector (M€/jr) & 27 & 37,5 \\
\hline Tijd benodigd voor invoering maatregel (jr) & $\begin{array}{l}\text { Invoering van maatre } \\
\text { direct mogelijk. } \\
\text { Invoering van maatre } \\
\text { pas mogelijk als vrije } \\
\text { beschikbaar komt. }\end{array}$ & $\begin{array}{l}-20 \mathrm{~g} / \mathrm{kg} \text { is technisch } \\
-30 \mathrm{~g} / \mathrm{kg} \text { is op termijn } \\
\text { nozuur glycine }\end{array}$ \\
\hline Termijn waarop effect wordt bereikt (jr) & $\begin{array}{l}\text { Invoering van maatre } \\
\text { effect. }\end{array}$ & resulteert direct in \\
\hline Afdwingbaarheid en instrumentatie & & \\
\hline $\begin{array}{l}\text { Verplicht in te voeren via wet- en regelgeving } \\
\text { (ja/nee) }\end{array}$ & $\begin{array}{l}\text { Ja, is geschikt als red } \\
\text { welke zou kunnen wo } \\
\text { bijlage } 2 \text { van de Rav. }\end{array}$ & $\begin{array}{l}\text { ende voermaatregel, } \\
\text { opgenomen in }\end{array}$ \\
\hline $\begin{array}{l}\text { Vrijwillig in te voeren via kennisdeling en stimulering } \\
\text { (ja/nee) }\end{array}$ & $\begin{array}{l}\text { Nee, vanwege het (gr } \\
\text { verminderde producti } \\
\text { saldovermindering. }\end{array}$ & $\begin{array}{l}\text { risico op } \\
\text { ultaten en }\end{array}$ \\
\hline Vrijwillige afspraak (ja/nee) & Nee, vanwege reden $\mathrm{r}$ & Doven aangegeven. \\
\hline
\end{tabular}

\section{Toelichting maatregel}

Een verlaging van het ruw eiwitgehalte in het voer resulteert in een verlaging van de stikstofuitscheiding in de mest. Dit resulteert in een verminderde uitscheiding van urinezuur en hierdoor een verminderd risico op de vorming van ammoniak. Het verlagen van het eiwitgehalte gaat vaak gepaard met een lagere wateropname en drogere mest wat eveneens de omzetting van stikstof naar ammoniak beïnvloedt.

De maatregel betreft het toepassen van veevoer waarvan het (ruw) eiwitgehalte ten opzichte van de huidige standaard met $20 \mathrm{~g} / \mathrm{kg}$ of $30 \mathrm{~g} / \mathrm{kg}$ is verlaagd. Bij de laatste is het wel nodig dat meer vrije aminozuren beschikbaar komen. Het standaard ruw eiwitgehalte in vleeskuikenvoer is afhankelijk van de leeftijd (fasen voeding) en neemt af van $215 \mathrm{~g} / \mathrm{kg}$ (startvoer) tot $200 \mathrm{~g} / \mathrm{kg}$ (eind-/afmestvoer). Tabel 3 geeft huidig eiwitgift en de eiwitgift op basis van een reductie van $20 \mathrm{~g} / \mathrm{kg}$. 
Tabel 3. Huidige eiwitgehalte in het voer (standaard) en laag eiwitgehalte $(-20 \mathrm{~g} / \mathrm{kg})$ bij 4 fasen voeding

\begin{tabular}{llll}
\hline Leeftijd dgn & Standaard & Eiwitgehalte in voer, g/kg \\
& & -20 & Laag eiwit \\
\hline $0-10$ & 215 & 215 & -30 \\
$10-17$ & 210 & 190 & 215 \\
$17-28$ & 205 & 185 & 180 \\
$28-$ afleveren & 200 & 180 & 175 \\
\hline
\end{tabular}

\section{Toelichting praktische implementatie}

Vleeskuikenhouders staan veelal huiverig tegenover het verlagen van het ruw eiwitgehalte van het voer, aangezien dit het risico vergroot van een verslechtering van de productieresultaten en dus bedrijfsinkomen. Momenteel is het nog niet zo dat met laag eiwitvoeders vergelijkbare productieresultaten behaald kunnen worden, laat staan dat men eenzelfde inkomen weet te generen. Invoering zal dan ook deels afhankelijk zijn van de beschikbaarheid en kostprijs van vrije aminozuren. Er zijn aanwijzingen dat het beschikbaar komen van vrij glycine mogelijk de verslechtering van de productieresultaten kan voorkomen. De voerprijs zal echter stijgen wanneer het eiwitgehalte wordt verlaagd, omdat er meer vrije aminozuren aan het voer moeten worden toegevoegd om de aminozurenbehoefte van het dier te dekken. Dit verhoogt de kostprijs zonder dat hier extra opbrengsten tegenover staan.

\section{Toelichting kosten}

Verlaging van het Re-gehalte van het voer met $20 \mathrm{~g} / \mathrm{kg}$ leidt tot een toename van de voerprijs met circa 7\% (Persoonlijke mededeling Van Harn). Per opgehokt vleeskuiken bedragen de voerkosten volgens de Kwantitatieve Informatie Veehouderij (KWIN-V) $€ 1,13$. Een toename van $7 \%$ betekent $€$ 0,08 per kuiken. In Nederland werden gemiddeld 45 miljoen vleeskuikens gehouden (2012-2014, Bron CBS). Er worden ca. 7,5 rondes per jaar behaald, waardoor op jaarbasis 340 miljoen kuikens worden afgeleverd. De totale jaarkosten bedragen daarmee $€ 27$ miljoen.

Verlaging van Re-gehalte van voer met $30 \mathrm{~g} / \mathrm{kg}$ leidt tot een toename van de voerprijs met circa $10 \%$ (Persoonlijke mededeling Van Harn). Per opgehokt vleeskuiken bedragen de voerkosten volgens KWIN-V $€ 1,13$. Een toename van $10 \%$ betekent $€ 0,11$ per kuiken. De totale jaarkosten bedragen daarmee $€ 37,5$ miljoen. 


\subsubsection{Factsheet 14. Verlagen eiwitgehalte voer van leghennen}

\section{Verlagen van het ruw eiwitgehalte van het voer (leghennen)}

De maatregel verlaagt de eiwitgift waardoor de uitscheiding van urinezuur vermindert en daarmee het risico op de vorming van ammoniak.

Wanneer dit resulteert in een afname van het ruw eiwitgehalte in het voer van $15 \mathrm{~g} / \mathrm{kg}$ zal de ammoniakemissie uit de stal met 15\% afnemen, bij een afname van $25 \mathrm{~g} / \mathrm{kg}$ ruw eiwit zal de emissiereductie $25 \%$ zijn.

\begin{tabular}{|c|c|c|}
\hline \multicolumn{3}{|l|}{ Tijdpad } \\
\hline Effectiviteit reductie & 2020 & 2030 \\
\hline & $R E=-15 \mathrm{~g} / \mathrm{kg}$ voer & $R E=-15 \mathrm{~g} / \mathrm{kg}$ voer \\
\hline Bij landelijke maatregel: emissiedaling (kton N/jr) & 0,6 & 1,1 \\
\hline $\begin{array}{l}\text { Implementatie } \\
\text { (kosteneffectiviteit en tijdpad) }\end{array}$ & 2020 & 2030 \\
\hline Kosteneffectiviteit (M€/kton $\mathrm{N}$ ) & 43 & 39 \\
\hline Investeringskosten voor de sector (M€) & - & - \\
\hline Operationele kosten voor de sector (M€/jr) & 27 & 41 \\
\hline Tijd benodigd voor invoering maatregel (jr) & \multicolumn{2}{|c|}{$\begin{array}{l}\text { Invoering van }-15 \mathrm{~g} / \mathrm{kg} \text { maatregel is direct } \\
\text { mogelijk. Invoering van maatregel }-25 \mathrm{~g} / \mathrm{kg} \\
\text { pas mogelijk als op termijn vrije aminozuur } \\
\text { glycine beschikbaar komt. }\end{array}$} \\
\hline Termijn waarop effect wordt bereikt (jr) & \multicolumn{2}{|c|}{$\begin{array}{l}\text { Invoering van maatregel resulteert direct in } \\
\text { effect. }\end{array}$} \\
\hline \multicolumn{3}{|l|}{ Afdwingbaarheid en instrumentatie } \\
\hline $\begin{array}{l}\text { Verplicht in te voeren via wet- en regelgeving } \\
\text { (ja/nee) }\end{array}$ & \multicolumn{2}{|c|}{$\begin{array}{l}\text { Ja, is geschikt als reducerende voermaatregel, } \\
\text { welke zou kunnen worden opgenomen in } \\
\text { bijlage } 2 \text { van de Rav. }\end{array}$} \\
\hline $\begin{array}{l}\text { Vrijwillig in te voeren via kennisdeling en stimulering } \\
\text { (ja/nee) }\end{array}$ & \multicolumn{2}{|c|}{$\begin{array}{l}\text { Nee, vanwege het risico op verminderde } \\
\text { productieresultaten en saldovermindering. } \\
\text { Invoering zal ook deels afhankelijk zijn van de } \\
\text { beschikbaarheid en kostprijs van vrije } \\
\text { aminozuren. }\end{array}$} \\
\hline Vrijwillige afspraak (ja/nee) & \multicolumn{2}{|c|}{ Nee, vanwege reden hierboven aangegeven. } \\
\hline
\end{tabular}

\section{Toelichting maatregel}

Een verlaging van het ruw eiwitgehalte in het voer resulteert in een verlaging van de stikstofuitscheiding in de mest. Dit resulteert in een verminderde uitscheiding van urinezuur en hierdoor een verminderd risico op de vorming van ammoniak. Het verlagen van het eiwitgehalte gaat vaak gepaard met een lagere wateropname en drogere mest wat eveneens de omzetting van stikstof naar ammoniak beïnvloedt.

De maatregel betreft het toepassen van veevoer waarvan het (ruw) eiwitgehalte ten opzichte van de huidige standaard met $15 \mathrm{~g} / \mathrm{kg}$ en $25 \mathrm{~g} / \mathrm{kg}$ is verlaagd. Om tegenvallende productieresultaten te voorkomen is aanvulling nodig in de vorm van vrije aminozuren. Het standaard ruw eiwitgehalte in leghennenvoer is gedurende de gehele legperiode redelijk constant en schommelt tussen de 155-160 $\mathrm{g} / \mathrm{kg}$ (WOT/TAN, 2013). 


\section{Toelichting kosten}

Verlaging van Re-gehalte van voer met $30 \mathrm{~g} / \mathrm{kg}$ leidt tot een toename van de voerprijs met circa $16 \%$ (Veldkamp et al., 2012). Verlaging met $15 \mathrm{~g} / \mathrm{kg}$ zal dan naar schatting een toename van de voerprijs van $8 \%$ geven. Per opgehokte leghen bedragen de voerkosten volgens KWIN-V $€ 13,50$ per ronde, ofwel $€ 10$ per jaar. Een toename van $8 \%$ betekent $€ 0,80$ per leghen. In Nederland werden gemiddeld 34 miljoen leghennen gehouden (2012-2014, Bron CBS). De totale jaarkosten bedragen daarmee $€ 27$ miljoen.

Verlaging van Re-gehalte van voer met $25 \mathrm{~g} / \mathrm{kg}$ leidt tot een toename van de voerprijs met circa $12 \%$ (schatting ontleend aan Veldkamp et al., 2012). Een toename van $12 \%$ betekent $€ 1,20$ per leghen. De totale jaarkosten bedragen daarmee $€ 41$ miljoen. 


\subsection{Varkens}

\subsubsection{Factsheet 15. Verlagen van eiwit in voer van zeugen met biggen}

De voergegevens worden berekend per diercategorie afzonderlijk. De door WUM en NEMA berekende cijfers betreffen zeugen met biggen. Om de cijfers van biggen, guste- en dragende zeugen en kraamzeugen te combineren tot één getal per gemiddeld aanwezige zeug op een bedrijf berekenen we dat een zeug $25 \%$ van de tijd in een kraamstal ligt en $75 \%$ van de tijd in de guste- en dragende zeugenstal. Per zeug zijn op het bedrijf 4 biggenplaatsen aanwezig. Omdat dit een gecombineerde berekening is zijn gelijke voereiwitreducties doorgerekend voor dragende en lacterende zeugen en biggen. In de praktijk zou het eiwitgehalte in biggenvoer en kraamzeugenvoer verder verlaagd kunnen worden dan in voer voor dragende zeugen. De ammoniakemissiereductie zou dan hoger zijn, evenals de voerkosten door toevoeging van meer essentiële aminozuren.

Veel varkensstallen hebben luchtwassers. Het is niet logisch dat boeren die geïnvesteerd hebben in een luchtwasser ook nog maatregelen in de stal gaan doorvoeren, aangezien dit maar een fractie $\mathrm{NH}_{3}$ oplevert door de reductie van de luchtwassers. Hiervoor wordt gecorrigeerd. Op basis van de gegevens in de Landbouwtelling blijkt dat ca. $40 \%$ van de varkens gehuisvest zijn in stallen met een luchtwasser. Voor onderstaande maatregelen is dus een maximale implementatie van $60 \%$ berekend.

\section{Verlagen van het ruw eiwitgehalte van het voer van zeugen met biggen}

De maatregel betreft het toepassen van diervoeder waarvan het (ruw) eiwitgehalte ten opzichte van een referentie wordt verlaagd. Voor biggenvoer is de referentie $175 \mathrm{~g} / \mathrm{kg} \mathrm{RE}$, voor dragende zeugen $135 \mathrm{~g} / \mathrm{kg}$ en voor kraamzeugen $155 \mathrm{~g} / \mathrm{kg}$.

De maatregel gaat uit van een reductie van ruw eiwit in het voer van $10 \mathrm{~g} / \mathrm{kg}$ RE voor 2020 en van 20 $\mathrm{g} / \mathrm{kg}$ RE voor 2030. De verteerbaarheid van het RE (VC-RE) neemt voor beide perioden respectievelijk $1 \%$ en $1.5 \%$ af. Een lagere verteerbaarheid betekent ook minder TAN in de urine.

\begin{tabular}{|c|c|c|}
\hline \multicolumn{3}{|l|}{ Tijdpad } \\
\hline Effectiviteit reductie & 2020 & 2030 \\
\hline & $\mathrm{RE}=-10 \mathrm{~g} / \mathrm{kg}$ voer & $\mathrm{RE}=-20 \mathrm{~g} / \mathrm{kg}$ voer \\
\hline Bij landelijke maatregel: emissiedaling (kton N/jr) & 0,7 & 1,0 \\
\hline $\begin{array}{l}\text { Implementatie } \\
\text { (kosteneffectiviteit en tijdpad) }\end{array}$ & 2020 & 2030 \\
\hline Kosteneffectiviteit ( $€ /$ kton $N)$ & $-0,7$ & 0,07 \\
\hline Investeringskosten voor de sector ( $\mathrm{mln} . €$ ) & - & - \\
\hline Operationele kosten voor de sector ( $\mathrm{mln} . € / \mathrm{jr}$ ) & $-0,5$ & 0,07 \\
\hline Tijd benodigd voor invoering maatregel (jr) & \multicolumn{2}{|c|}{$\begin{array}{l}\text { Invoering van maatregel }-10 \mathrm{~g} / \mathrm{kg} \text { is direct } \\
\text { mogelijk. } \\
\text { Invoering van maatregel }-20 \mathrm{~g} / \mathrm{kg} \text { is mogelijk na } \\
\text { beschikbaar komen van vrij isoleucine. }\end{array}$} \\
\hline Termijn waarop effect wordt bereikt (jr) & \multicolumn{2}{|c|}{$\begin{array}{l}\text { Invoering van maatregel resulteert direct in } \\
\text { effect. }\end{array}$} \\
\hline \multicolumn{3}{|l|}{ Afdwingbaarheid en instrumentatie } \\
\hline $\begin{array}{l}\text { Verplicht in te voeren via wet- en regelgeving } \\
\text { (ja/nee) }\end{array}$ & \multicolumn{2}{|c|}{$\begin{array}{l}\text { Geschikt als reducerende voermaatregel in } \\
\text { bijlage } 2 \text { van de Rav, (controle) systematiek } \\
\text { behoeft nadere uitwerking. }\end{array}$} \\
\hline $\begin{array}{l}\text { Vrijwillig in te voeren via kennisdeling en } \\
\text { stimulering ( } \mathrm{ja} / \mathrm{nee})\end{array}$ & \multicolumn{2}{|c|}{$\begin{array}{l}\text { Deels, afhankelijk van de kostprijs van vrije } \\
\text { aminozuren en evt. aanvullende voordelen op } \\
\text { diergezondheid en mestconsistentie. }\end{array}$} \\
\hline Vrijwillige afspraak (ja/nee) & \multicolumn{2}{|c|}{ Niet vrijwillig bij (sterke) toename kostprijs. } \\
\hline
\end{tabular}




\section{Toelichting maatregel}

Een verlaging van het ruw eiwitgehalte in het voer resulteert in een verlaging van de stikstofuitscheiding in de urine (TAN-excretie). TAN is de bron van ammoniak, een verlaging van de TAN in de mest zal de ammoniakemissie verlagen. Om in de aminozurenbehoefte van het dier te voorzien gaat de verlaging van het ruw eiwitgehalte gepaard met een hoger aandeel zuivere aminozuren en/of een toename van voederingrediënten (grondstoffen) met een aminozurenpatroon wat beter aansluit bij de behoefte van het dier. Ook een verbetering van de aminozurenverteerbaarheid draagt bij aan een verlaging van het ruw eiwitgehalte, maar dit verlaagt m.n. de stikstofexcretie in de feces (geen TAN) wat minder bijdraagt aan de ammoniakemissie.

\section{Toelichting praktijkimplementatie}

De verlaging van het ruw eiwitgehalte wordt begrensd door de beschikbaarheid van essentiële aminozuren in zuivere vorm. Op dit moment betreft dit lysine, methionine, threonine, tryptopfaan en valine. In de toekomst komen wellicht meer aminozuren in deze vorm beschikbaar wanneer hiervoor voldoende marktvraag is. Isoleucine is hierbij waarschijnlijk het eerstvolgende beschikbare aminozuur. Uiteindelijk wordt een daling begrensd door de behoefte aan de som aan niet-essentiële aminozuren ( totaal eiwit) en het feit dat reguliere grondstoffen zoals granen tevens een bepaalde hoeveelheid eiwit bevatten.

\section{Toelichting kosten}

Verlaging van Re met $10 \mathrm{~g} / \mathrm{kg}$ bij biggen leidt tot een voerprijsdaling van $€ 0,09$ per $100 \mathrm{~kg}$ voer en circa $€ 0,17$ per biggenplaats per jaar. Er zijn ca. 4 miljoen biggenplaatsen in Nederland (afgeleid van CBS). Besparing op kosten bedraagt totaal $€ 0,7$ miljoen per jaar.

Verlaging van Re met $20 \mathrm{~g} / \mathrm{kg}$ bij biggen leidt tot een voerprijsstijging van $€ 0,01$ per $100 \mathrm{~kg}$ voer en circa $€ 0,02$ per biggenplaats per jaar. Er zijn ca. 4 miljoen biggenplaatsen in Nederland (afgeleid van CBS). Extra kosten bedragen totaal $€ 80.000$ per jaar.

Verlaging van Re met $10 \mathrm{~g} / \mathrm{kg}$ bij guste en dragende zeugen leidt tot een voerprijsstijging van $€ 0,05$ per $100 \mathrm{~kg}$ voer en $€ 0,42$ per guste en dragende zeugenplaats per jaar. Er zijn ca. 850 duizend guste en dragende zeugen in Nederland (afgeleid van CBS). Extra kosten bedragen totaal $€ 357$ duizend per jaar.

Verlaging van Re met $20 \mathrm{~g} / \mathrm{kg}$ bij guste en dragende zeugen leidt tot een voerprijsstijging van $€ 0,31$ per $100 \mathrm{~kg}$ voer en circa $€ 2,60$ per guste en dragende zeugenplaats per jaar. Er zijn ca. 850 duizend guste en dragende zeugen in Nederland (afgeleid van CBS). Extra kosten bedragen totaal $€ 2,2$ miljoen per jaar.

Verlaging van Re met $10 \mathrm{~g} / \mathrm{kg}$ bij kraamzeugen leidt tot een voerprijsstijging van (schatting) $€ 1,00$ per $100 \mathrm{~kg}$ voer en circa $€ 20$ per kraamzeugenplaats per jaar. Er zijn ca. 180 duizend kraamzeugen in Nederland (afgeleid van CBS). Extra kosten bedragen totaal $€ 1,6$ miljoen per jaar.

Voor een verdere verlaging met $10 \mathrm{~g} / \mathrm{kg}$ (dus totaal $20 \mathrm{~g} / \mathrm{kg}$ ) ligt geen informatie. Wel is er in het kader van Proeftuin Natura 2000 een inschatting gemaakt voor verlaging met $12 \mathrm{~g} / \mathrm{kg}$. Dit leidt tot een voerprijsstijging van $€ 2,58$ per $100 \mathrm{~kg}$ voer en circa $€ 50$ per zeugenplaats per jaar. Extra kosten bedragen $€ 9$ miljoen per jaar. Aanname dat dit wel $€ 100$ per zeugenplaats wordt als Re totaal 20 $\mathrm{g} / \mathrm{kg}$ lager moet. Extra kosten bedragen dan $€ 18$ miljoen per jaar.

Bron: Aarnink et al. Rapport 591 uit 2012. 


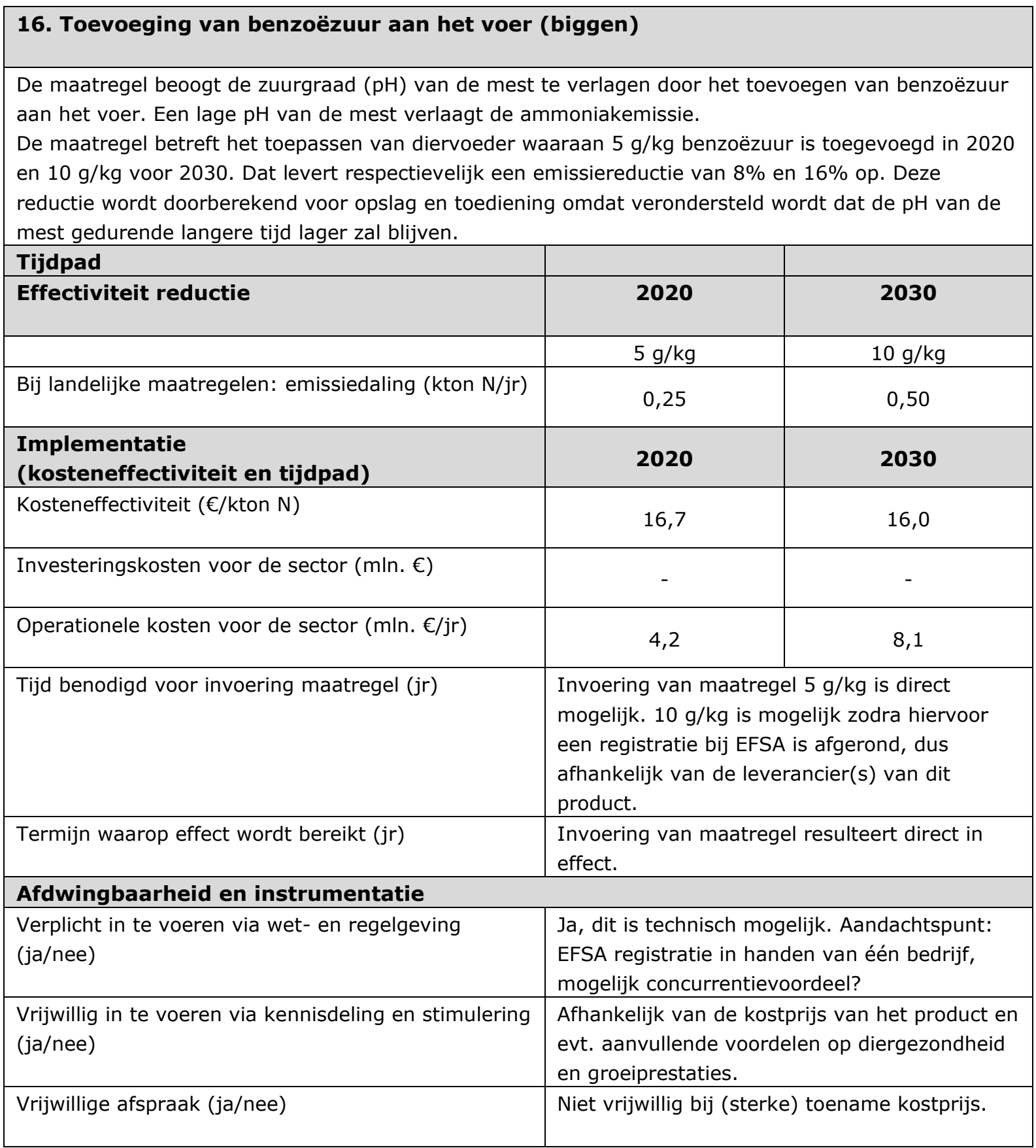

\section{Toelichting maatregel}

Benzoëzuur wordt in het lichaam omgezet in hippuurzuur wat vervolgens via de urine wordt uitgescheiden. Hippuurzuur zorgt voor een $\mathrm{pH}$ verlaging van urine en mengmest, waardoor de ammoniakemissie vanaf de roostervloer en uit de mestkelder wordt verlaagd.

De maatregel is doorgerekend voor zeugen incl. biggen. Echter het toevoegen van benzoëzuur aan zeugenvoer wordt op voorhand te duur geacht en daarom buiten beschouwing gelaten. Op basis van de eerder beschreven verhouding tussen biggen- en zeugenplaatsen kan berekend worden dat 30\% van de ammoniakemissie door biggen veroorzaakt wordt. Van de doorberekende reductie voor zeugen met biggen van 0,4 en 0,8 voor 2020 en 2030 respectievelijk is 30\% als bijdrage van de biggen berekend. Dit is verwerkt in bovenstaande tabel.

\section{Toelichting praktische implementatie}

Voor de hoge dosering is in het kader van de voedselveiligheid nog een registratie bij de EFSA (European Food Safety Authority) vereist. De EFSA registratie voor de lage dosering is in handen van één bedrijf. Dit kan een remmende werking hebben op de implementatiesnelheid. 
Voor biggen wordt het toevoegmiddel al op kleine schaal toegepast in de praktijk. Het feit dat benzoëzuur ook positief werkt op de diergezondheid en de groei, waarbij het antibioticum-gebruik beperkt kan worden is een bijkomend voordeel.

\section{Toelichting kosten}

Toevoeging van benzoëzuur met $5 \mathrm{~g} / \mathrm{kg}$ bij biggen leidt tot een voerprijsstijging van $€ 0,76$ per $100 \mathrm{~kg}$ voer en circa $€ 1,45$ per biggenplaats per jaar. Er zijn ca. 4 miljoen biggenplaatsen in Nederland (afgeleid van CBS). Extra kosten bedragen totaal $€ 5,8$ miljoen per jaar.

Toevoeging van benzoëzuur met $10 \mathrm{~g} / \mathrm{kg}$ bij biggen leidt tot een voerprijsstijging van $€ 1,50$ per $100 \mathrm{~kg}$ voer en circa $€ 2,86$ per biggenplaats per jaar. Er zijn ca. 4 miljoen biggenplaatsen in Nederland (afgeleid van CBS). Extra kosten bedragen totaal $€ 11,4$ miljoen per jaar.

Bron: Aarnink et al. Rapport 591 uit 2012.

\subsubsection{Factsheet 17 . Verlagen van eiwit in voer van vleesvarkens}

\section{Verlagen van het ruw eiwitgehalte van het voer (vleesvarkens)}

Toelichting: zie zeugen met biggen.

De maatregel betreft het toepassen van diervoeder waarvan het (ruw) eiwitgehalte ten opzichte van een referentie van $160 \mathrm{~g} / \mathrm{kg}$ wordt verlaagd. De verlaging bedraagt $15 \mathrm{~g} / \mathrm{kg}$ in 2020 en $30 \mathrm{~g} / \mathrm{kg}$ in 2030. De VC-RE daalt respectievelijk $1 \%$ en $2 \%$.

\begin{tabular}{|c|c|c|}
\hline \multicolumn{3}{|l|}{ Tijdpad } \\
\hline Effectiviteit reductie & 2020 & 2030 \\
\hline & $\mathrm{RE}=-15 \mathrm{~g} / \mathrm{kg}$ voer & $\mathrm{RE}=-30 \mathrm{~g} / \mathrm{kg}$ voer \\
\hline Bij landelijke maatregelen: emissiedaling (kton N/jr) & 1,5 & 3,1 \\
\hline $\begin{array}{l}\text { Implementatie } \\
\text { (kosteneffectiviteit en tijdpad) }\end{array}$ & 2020 & 2030 \\
\hline Kosteneffectiviteit ( $€ /$ kton $N)$ & 3,2 & 5,1 \\
\hline Investeringskosten voor de sector ( $\mathrm{mln} . €$ ) & - & - \\
\hline Operationele kosten voor de sector ( $\mathrm{mln} . € / \mathrm{jr}$ ) & 5,0 & 15,5 \\
\hline Tijd benodigd voor invoering maatregel (jr) & \multicolumn{2}{|c|}{$\begin{array}{l}\text { Invoering van maatregel }-15 \mathrm{~g} / \mathrm{kg} \text { is direct } \\
\text { mogelijk. } \\
\text { Invoering van maatregel }-30 \mathrm{~g} / \mathrm{kg} \text { is mogelijk } \\
\text { na beschikbaar komen van vrij isoleucine. }\end{array}$} \\
\hline Termijn waarop effect wordt bereikt (jr) & \multicolumn{2}{|c|}{$\begin{array}{l}\text { Invoering van maatregel resulteert direct in } \\
\text { effect. }\end{array}$} \\
\hline \multicolumn{3}{|l|}{ Afdwingbaarheid en instrumentatie } \\
\hline $\begin{array}{l}\text { Verplicht in te voeren via wet- en regelgeving } \\
\text { (ja/nee) }\end{array}$ & \multicolumn{2}{|c|}{$\begin{array}{l}\text { Geschikt als reducerende voermaatregel in } \\
\text { bijlage } 2 \text { van de Rav, (controle) systematiek } \\
\text { behoeft nadere uitwerking. }\end{array}$} \\
\hline $\begin{array}{l}\text { Vrijwillig in te voeren via kennisdeling en stimulering } \\
\text { (ja/nee) }\end{array}$ & \multicolumn{2}{|c|}{$\begin{array}{l}\text { Deels, afhankelijk van de kostprijs van vrije } \\
\text { aminozuren en evt. aanvullende voordelen op } \\
\text { diergezondheid en mestconsistentie. }\end{array}$} \\
\hline Vrijwillige afspraak (ja/nee) & \multicolumn{2}{|c|}{ Niet vrijwillig bij (sterke) toename kostprijs. } \\
\hline
\end{tabular}

\section{Toelichting maatregel}

Zie Factsheet 15 . Verlagen van eiwit in voer van zeugen met biggen. 


\section{Toelichting kosten}

Verlaging van Re met $15 \mathrm{~g} / \mathrm{kg}$ bij vleesvarkens leidt tot een voerprijsstijging van $€$ 0,25 per $100 \mathrm{~kg}$ voer en circa $€ 1,75$ per vleesvarkensplaats per jaar. Er zijn ca. 5,7 miljoen vleesvarkens in Nederland (afgeleid van CBS). Toename kosten bedraagt totaal $€ 10$ miljoen per jaar.

Verlaging van Re met $30 \mathrm{~g} / \mathrm{kg}$ bij vleesvarkens leidt tot een voerprijsstijging van $€$ 0,78 per $100 \mathrm{~kg}$ voer en circa $€ 5,40$ per vleesvarkensplaats per jaar. Er zijn ca. 5,7 miljoen vleesvarkens in Nederland (afgeleid van CBS). Extra kosten bedragen totaal $€ 31$ miljoen per jaar.

Bron: Aarnink et al. Rapport 591 uit 2012.

\subsubsection{Factsheet 18. Toevoegen van benzoëzuur aan voer van vleesvarkens}

\section{Toevoeging van benzoëzuur aan het voer (vleesvarkens)}

Toelichting: zie biggen.

De maatregel betreft het toepassen van diervoeder waaraan $0.5-1 \%$ benzoëzuur $(5 \mathrm{~g} / \mathrm{kg} \mathrm{c.q.} 10 \mathrm{~g} / \mathrm{kg})$ is toegevoegd. Wat een emissiereductie oplevert van 8 c.q. $16 \%$. Deze reductie wordt doorberekend voor opslag en toediening omdat verondersteld wordt dat de $\mathrm{pH}$ van de mest gedurende langere tijd lager zal blijven.

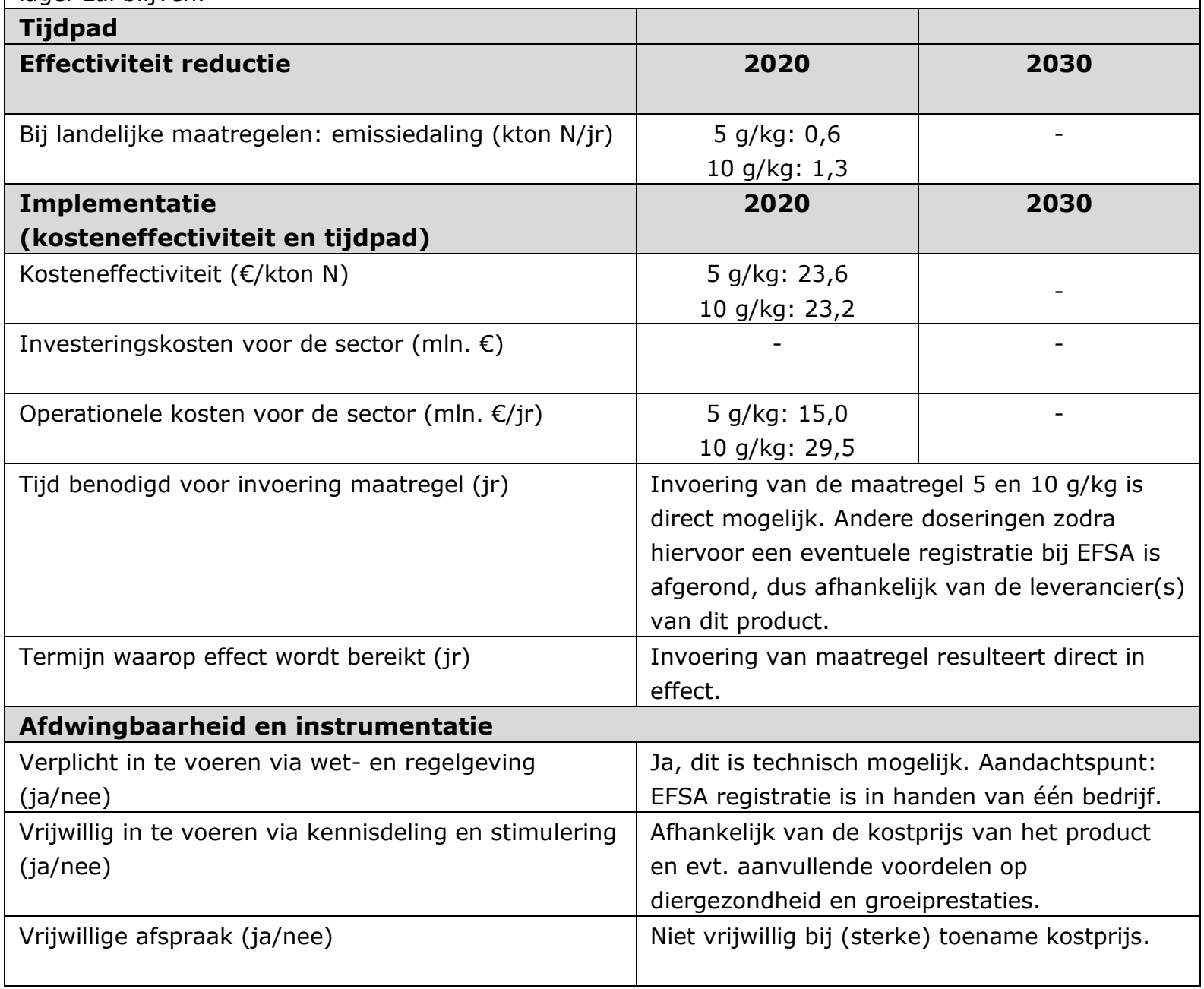

\section{Toelichting maatregel}

Zie Factsheet 16: Toevoegen benzoëzuur aan het voer van biggen.

\section{Toelichting praktische implementatie}

Zie Factsheet 16: Toevoegen benzoëzuur aan het voer van biggen. 


\section{Toelichting kosten}

Toevoeging van benzoëzuur met $5 \mathrm{~g} / \mathrm{kg}$ bij vleesvarkens leidt tot een voerprijsstijging van $€ 0,76$ per $100 \mathrm{~kg}$ voer en circa $€ 5,25$ per vleesvarkensplaats per jaar. Er zijn ca. 5,7 miljoen vleesvarkensplaatsen in Nederland (afgeleid van CBS). Extra kosten bedragen totaal $€ 30$ miljoen per jaar.

Toevoeging van benzoëzuur met $10 \mathrm{~g} / \mathrm{kg}$ bij vleesvarkens leidt tot een voerprijsstijging van $€ 1,50$ per $100 \mathrm{~kg}$ voer en $€ 10,36$ per vleesvarkensplaats per jaar. Er zijn ca. 5,7 miljoen vleesvarkensplaatsen in Nederland (afgeleid van CBS). Extra kosten bedragen totaal $€ 59$ miljoen per jaar.

Bron: Aarnink et al. Rapport 591 uit 2012.

\subsection{Rundvee}

\subsubsection{Factsheet 19. TAN-excretie melkvee verminderen via voerspoor}

\section{TAN-excretie verminderen op het melkveebedrijf met voermaatregelen De maatregel voorziet in een samenhangend geheel van voermaatregelen om de TAN-excretie te verminderen. Dit is voor alle melkveebedrijven in Nederland mogelijk, omdat het voerspoor veel mogelijkheden biedt. Vrijwel ieder Nederlands melkveebedrijf kan in het pakket van maatregelen in het voerspoor passende maatregelen vinden. De haalbare reductie ten opzichte van 2014 is voor een individueel bedrijf afhankelijk van de mate waarin het bedrijf het voerspoor al heeft benut.}

\begin{tabular}{|c|c|c|}
\hline Effectiviteit reductie & 2020 & 2030 \\
\hline Bij landelijke maatregelen: emissiedaling (kton N/jr) & 1,3 & 4,4 \\
\hline $\begin{array}{l}\text { Implementatie } \\
\text { (kosteneffectiviteit en tijdpad) }\end{array}$ & 2020 & 2030 \\
\hline Kosteneffectiviteit $(€ /$ kton $N)$ & $€-30 \mathrm{mln} /$ kton $\mathrm{N}$ & $€-37 \mathrm{mln} / \mathrm{kton} \mathrm{N}$ \\
\hline Investeringskosten voor de sector $(€)$ & - & - \\
\hline Operationele kosten voor de sector (M€/jr) & -96 & -320 \\
\hline Tijd benodigd voor invoering maatregel (jr) & \multicolumn{2}{|c|}{$\begin{array}{l}\text { De maatregel kan direct worden toegepast, } \\
\text { maar vraagt een leertraject van de } \\
\text { melkveehouder voordat volledige benutting } \\
\text { van de potentie wordt bereikt. }\end{array}$} \\
\hline Termijn waarop effect wordt bereikt (jr) & \multicolumn{2}{|c|}{$\begin{array}{l}\text { Direct effect bij implementatie, maar } \\
\text { geleidelijk toenemend afhankelijk van } \\
\text { leerproces veehouder. }\end{array}$} \\
\hline \multicolumn{3}{|l|}{ Afdwingbaarheid en instrumentatie } \\
\hline Verplicht in te voeren via wet- en regelgeving (ja/nee) & \multicolumn{2}{|l|}{ Ja. } \\
\hline $\begin{array}{l}\text { Vrijwillig in te voeren via kennisdeling en stimulering } \\
\text { (ja/nee) }\end{array}$ & \multicolumn{2}{|c|}{$\begin{array}{l}\text { Twijfelachtig. } \\
\text { Ja, omdat de maatregel in principe geld } \\
\text { oplevert. } \\
\text { Nee, omdat met managen van andere } \\
\text { verplichtingen meer is te } \\
\text { verdienen/besparen en dus daar de } \\
\text { aandacht en energie naar toe gaat. }\end{array}$} \\
\hline Vrijwillige afspraak (ja/nee) & \multicolumn{2}{|c|}{$\begin{array}{l}\text { Afhankelijk hoeveel van het } \\
\text { reductiepotentieel gehaald moet worden } \\
\text { m.a.w. afhankelijk van hoever een } \\
\text { veehouder het leerproces wil doorlopen } \\
\text { (zonder andere incentive dan kosten } \\
\text { besparen via efficiënte voeding). }\end{array}$} \\
\hline
\end{tabular}




\section{Toelichting maatregel}

In Bijlage 3 wordt toegelicht op welke wijze de verwachte emissiereductie als gevolg van het verlagen van de TAN-excretie op het melkveebedrijf is ingeschat.

Bij de uitwerking van deze maatregel is aangenomen dat het reductie-effect voornamelijk via het melkveedeel van de melkveestapel moet worden bereikt. In principe zou je ook de TAN-excretie van jongvee kunnen verlagen door kwalitatief beter te voeren. Gedacht wordt dat dit in de praktijk wel mogelijk is, maar lastig uitvoerbaar. In de praktijk wordt nl. het voer wat bij de melkkoeien over is voor het jongvee geschoven, waardoor van rantsoenoptimalisatie voor jongvee geen sprake is.

Bovendien is niet al het ruwvoer dat op een bedrijf aanwezig is geschikt om op te nemen in scherp gevoerd melkvee (afhankelijk van oogstmoment, voorjaar/najaar en van het weer tijdens de groei en/of tijdens inkuilen). Jongvee krijgt in de regel het voor melkvee ongeschikte voer. De getallen in Bijlage 3 zijn voor het melkveebedrijf als geheel aan de hoge kant, omdat het jongvee daarin niet is meegenomen. Volgens de forfaits voor ammoniakemissie is het jongveedeel op een gemiddeld NL melkveebedrijf ca. $20 \%$ van de ammoniakemissie. Onder aanname dat de ammoniakemissie van jongvee niet zal dalen betekent dat dat de reductie van de veestapelemissie op het melkveebedrijf ca. $80 \%$ van de reductie van de melkveestapel zal zijn (voor NL is dat voor 2020 en 2030 respectievelijk ca. $3,5 \%$ en ca. $12,5 \%)$.

\section{Toelichting praktische implementatie}

Het verlagen van de TAN-excretie door de veestapel is niet alleen effectief in het reduceren van de ammoniakemissie, maar gaat ook gepaard met een verbetering van de voerefficiëntie en leidt daarmee in principe tot verlaging van de (voer)kosten. De reden dat deze reductiepotentie nog niet volledig wordt benut is enerzijds ontbrekende kennis en kunde bij de veehouder en anderzijds de noodzaak en druk op de veehouder om zich met andere zaken bezig te houden. Bij de inschatting van de reductiepotentie en praktische implementatie is er van uitgegaan dat in 2030 zowel de kennis en kunde van de veehouder op peil zijn, als voldoende druk om de ammoniakemissie van het bedrijf te verminderen. Verder is aangenomen dat die ontwikkeling zich van nu tot 2030 geleidelijk voltrekt. Toepassen van deze doelmaatregel gebeurt via het voer- en diermanagement en is daarmee een pakket van maatregelen. Vrijwel ieder Nederlands melkveebedrijf kan in dat pakket passende maatregelen vinden. Het gaat daarbij niet om de toepassing van afzonderlijke voermaatregelen, maar om de combinatie van maatregelen.

\section{Toelichting kosten}

Verhoging van melkproductie bij verbeterde voerefficiëntie en verlaging Re-gehalte voer, levert verbetering van arbeidsinkomen op. Tot 2020 is dit ca $€ 60$ per melkkoe; voor 1,6 miljoen mk dus $€$-96 miljoen. In 2030 is dit opgelopen tot $€ 200$ per melkkoe. Echter, efficiëntieverbetering is een doorlopende autonome ontwikkeling. En derhalve niet enkel toe te schrijven aan de ammoniakemissiereductie- maatregel. Er kan wel gesteld worden dat de maatregel geld oplevert. Dit is daarom kwalitatief opgenomen in de tabel. 


\section{$5 \quad$ Toediening}

\subsection{Algemeen}

Er zijn geen nieuwe technieken voorhanden om de mest emissiearm toe te dienen. De maatregelen voorzien in het combineren van bestaande technieken en maatregelen en een methode uit het verleden.

\subsubsection{Factsheet 20. Aanzuren van mest en zodenbemesting}

\section{Aangezuurde mest en zodenbemesting}

Mesttoediening met zodenbemester in combinatie met aanzuren van de mest vlak voor toediening. Aanzuren heeft effect op de emissie, waarbij de mate van aanzuren een belangrijke rol speelt (meer zuur, een lagere $\mathrm{pH}$, minder emissie). Mesttoediening met een sleepvoet en aanzuren met zwavelzuur is onderzocht; opties voor andere zuren. Het toegepaste zuur mag echter niet tot een extra of andere milieubelasting leiden.

Uitgegaan wordt van een emissiereductie van $25 \%$ bij zodenbemesting (ten opzichte van huidige emissiefactor van 19\%). In de berekeningen is uitgegaan van een emissiefactor van $14 \%$.

\begin{tabular}{|c|c|c|}
\hline Effectiviteit reductie & 2020 & 2030 \\
\hline Bij landelijke maatregel: emissiedaling (kton $\mathrm{N} / \mathrm{jr}$ ) & 2,4 & 6,1 \\
\hline $\begin{array}{l}\text { Implementatie } \\
\text { (kosteneffectiviteit en tijdpad) }\end{array}$ & 2020 & 2030 \\
\hline Kosteneffectiviteit (M€/kton N) & 20 & 39 \\
\hline Investeringskosten voor de sector (M€) & 14 & 72 \\
\hline Operationele kosten voor de sector ( $\mathrm{M} € / \mathrm{jr}$ ) & 48 & 240 \\
\hline Tijd benodigd voor invoering maatregel (jr) & \multicolumn{2}{|l|}{ 5-10 jaar } \\
\hline Termijn waarop effect wordt bereikt (jr) & \multicolumn{2}{|l|}{ 5-10 jaar } \\
\hline \multicolumn{3}{|l|}{ Afdwingbaarheid en instrumentatie } \\
\hline $\begin{array}{l}\text { Verplicht in te voeren via wet- en regelgeving } \\
(\mathrm{ja} / \mathrm{nee})\end{array}$ & \multicolumn{2}{|c|}{$\begin{array}{l}\text { Veel zal afhangen van noodzaak; verschillend } \\
\text { voor individuele bedrijven. Aanzuren is een } \\
\text { kostenpost en vergt bedrijfsaanpassing } \\
\text { (aanzuren mestopslag) of investering van } \\
\text { loonwerker (aanzuren op de machine). }\end{array}$} \\
\hline $\begin{array}{l}\text { Vrijwillig in te voeren via kennisdeling en } \\
\text { stimulering ( } \mathrm{ja} / \mathrm{nee})\end{array}$ & \multicolumn{2}{|c|}{$\begin{array}{l}\text { Veel zal afhangen van noodzaak; verschillend } \\
\text { voor individuele bedrijven. Aanzuren is een } \\
\text { kostenpost en vergt bedrijfsaanpassing } \\
\text { (aanzuren mestopslag) of investering van } \\
\text { loonwerker (aanzuren op de machine). }\end{array}$} \\
\hline Vrijwillige afspraak (ja/nee) & \multicolumn{2}{|c|}{$\begin{array}{l}\text { Veel zal afhangen van noodzaak; verschillend } \\
\text { voor individuele bedrijven. Aanzuren is een } \\
\text { kostenpost en vergt bedrijfsaanpassing } \\
\text { (aanzuren mestopslag) of investering van } \\
\text { loonwerker (aanzuren op de machine). }\end{array}$} \\
\hline
\end{tabular}




\section{Toelichting maatregel}

Aanzuren heeft effect op de emissie, waarbij de mate van aanzuren een belangrijke rol speelt: meer zuur, een lagere $\mathrm{pH}$, minder emissie (Bussink et al., 1994). Het toedienen van aangezuurde mest ( $\mathrm{pH}$ ca 6.2) met een sleepvoetenmachine leidde tot een gemiddelde emissiereductie van ca. $25 \%$ ten opzichte van niet aanzuren en toediening met sleepvoet (Huijsmans et al., 2015). Als deze lijn van emissiereductie doorgetrokken kan worden voor zodenbemesting, dan zou dit leiden tot een emissie van $14 \%$ bij toediening van aangezuurde mest met een zodenbemester (nog verder te onderbouwen).

\section{Toelichting praktische implementatie}

De keuze van het te gebruiken zuur bij het aanzuren van mest is van belang: het zuur mag niet tot een extra belasting van het milieu leiden. De keuze van het zuur wordt mede bepaald door de benodigde hoeveelheid om de $\mathrm{pH}$ verlaging te bereiken; dit is afhankelijk van de sterkte van het zuur. Het is technisch mogelijk om de mest aan te zuren kort voor of tijdens de toediening. Veiligheid vraagt extra aandacht, omdat met (sterke) zuren gewerkt wordt. Daarnaast speelt natuurlijk de handhaving/borging van het systeem.

\section{Toelichting kosten}

De kostenberekeningen zijn gemaakt op basis van de gegevens in Bussink et al. (2014) en Melse et al. (2015). De kosten voor aanzuren met HAc of HAC+C (koolstof) in de opslag bedragen ca. $€ 270$ per melkkoe of $€ 10$ per $\mathrm{m}^{3}$ mest. De benodigde investering bedraagt ruim $€ 500$ per koe. De kosten bestaan voor ca $25 \%$ uit vaste kosten (rente, afschrijving, onderhoud) en $75 \%$ uit variabele kosten (chemicaliën, energie e.d.).

Voor aanzuren tijdens de mesttoediening wordt aangenomen dat deze kosten gehalveerd worden, omdat slechts tot pH 6-6,5 hoeft te worden aangezuurd in plaats van pH 5,5 zoals in de stal. De kosten zijn dus de helft: $€ 3,75$ per $\mathrm{m}^{3}$ mest. $\mathrm{Er}$ is ca. 1,0 miljoen hectare grasland in Nederland, waarop 60 miljoen ton mest wordt uitgereden. De extra investeringen voor de aanzuurinstallatie op de zodenbemester bedragen $€ 1,20$ per $\mathrm{m}^{3}$ mest, dus totaal $€ 72$ miljoen. De jaarkosten hiervan (rente, afschrijving, onderhoud) zijn globaal $17 \%$, dus 0,20 per $\mathrm{m}^{3}$ mest. Totaal $€ 3,75+0,20=$ afgerond $€ 4$ per $\mathrm{m}^{3}$. Op basis hiervan zijn de jaarkosten $€ 240$ miljoen.

Als in $202020 \%$ geïmplementeerd is, dan dus $20 \%$ van deze bedragen.

Een loonwerker rijdt $30 \mathrm{~m}^{3}$ mest per uur uit; $250 \mathrm{~m}^{3}$ per dag. Dit gedurende 120 dagen in het jaar, maakt $30.000 \mathrm{~m}^{3}$ per combinatie.

Zodenbemester geeft investering $€ 35.000$, dan is dat $€ 1,17$ per $\mathrm{m}^{3}$. 


\subsubsection{Factsheet 21. Verbeteren van effectiviteit van toedieningstechnieken}

\section{Verbetering effectiviteit en borging huidige toedieningstechnieken}

Effectiviteit van huidige technieken verbeteren; nauwkeurigheid van werken op grasland en bouwland; differentiatie naar grondsoort. Is het werkresultaat na de mesttoediening overeenkomend met dat van een zodenbemester of sleepvoet/sleufkouter ? Nauwkeurig werken heeft alles te maken met mestgift, verdeelnauwkeurigheid van de mest over werkbreedte machine, bodemcondities en afstellingsmogelijkheden van de machine. De chauffeur speelt hierbij ook een belangrijke rol.

Effectiviteit van uitvoering bestaande maatregelen kan daarbij verbeteren door verbeterde borging. Borging kan een aspect zijn van eisen van de NVWA. In principe kan ook geborgd worden op de machine door registratie en sturing afstelling machine, opdat de mesttoediening netjes gebeurd.

Uitgegaan wordt van een emissiereductie van $25 \%$ bij zodenbemesting (ten opzichte van huidige emissiefactor van 19\%). In de berekeningen is uitgegaan van een emissiefactor van $14 \%$ voor zodenbemesting.

(Mogelijk straks nog wel onderscheid naar grondsoorten)

\begin{tabular}{|c|c|c|}
\hline Effectiviteit reductie & 2020 & 2030 \\
\hline Bij landelijke maatregel: emissiedaling (kton N/jr) & 2,4 & 6,1 \\
\hline $\begin{array}{l}\text { Implementatie } \\
\text { (kosteneffectiviteit en tijdpad) }\end{array}$ & 2020 & 2030 \\
\hline Kosteneffectiviteit (M€/kton $\mathrm{N}$ ) & 3,8 & 4,9 \\
\hline \multicolumn{3}{|l|}{ Investeringskosten voor de sector $(\mathrm{M} €$ ) } \\
\hline Operationele kosten voor de sector (M€/jr) & 9 & 30 \\
\hline Tijd benodigd voor invoering maatregel (jr) & \multicolumn{2}{|c|}{ 5-10 jaar } \\
\hline Termijn waarop effect wordt bereikt (jr) & \multicolumn{2}{|c|}{ 5-10 jaar } \\
\hline \multicolumn{3}{|l|}{ Afdwingbaarheid en instrumentatie } \\
\hline $\begin{array}{l}\text { Verplicht in te voeren via wet- en regelgeving } \\
(\mathrm{ja} / \text { nee })\end{array}$ & \multicolumn{2}{|c|}{$\begin{array}{l}\text { Het betreft 'netter' werken gepaard gaande } \\
\text { met betere borging. De borging is veelal een } \\
\text { overheidsaangelegenheid. Veel zal afhangen } \\
\text { van noodzaak; verschillend voor individuele } \\
\text { bedrijven. Het betreft met name een } \\
\text { investering van loonwerker die evt. machine } \\
\text { moet aanpassen of meer tijd en aandacht zal } \\
\text { moeten besteden aan de werkzaamheden. De } \\
\text { loonwerker zal de meerkosten willen } \\
\text { doorbelasten. }\end{array}$} \\
\hline $\begin{array}{l}\text { Vrijwillig in te voeren via kennisdeling en stimulering } \\
\text { (ja/nee) }\end{array}$ & \multicolumn{2}{|c|}{$\begin{array}{l}\text { Het 'netter' werken kan gestimuleerd worden. } \\
\text { Veel zal afhangen van noodzaak; verschillend } \\
\text { voor individuele bedrijven. Het betreft met } \\
\text { name een investering van loonwerker die evt. } \\
\text { machine moet aanpassen of meer tijd en } \\
\text { aandacht zal moeten besteden aan de } \\
\text { werkzaamheden. De loonwerker zal de } \\
\text { meerkosten willen doorbelasten. }\end{array}$} \\
\hline Vrijwillige afspraak (ja/nee) & \multicolumn{2}{|c|}{ Zie stimulering. } \\
\hline
\end{tabular}




\section{Toelichting maatregel}

$\mathrm{Na}$ de introductie van zodenbemesting begin jaren ' 90 is er een trend over de jaren vastgesteld waarbij de ammoniakemissie bij zodenbemesting is gestegen (Huijsmans \& Schils, 2009). Deze hogere emissie is mogelijk te verklaren door een andere uitwerking/toepassing van zodenbemesting in de praktijk. Hierbij valt o.a. te denken aan minder diep werken (meer richting sleufkouter), zodat minder trekkracht gevraagd wordt en daarmee de capaciteit van de machine kan stijgen of brandstof kan worden bespaard. Verondersteld wordt dat weer een lager niveau voor de emissie bereikt kan worden door een goede werking (o.a. door afstelling), waarbij alle mest goed in sleuven wordt toegediend. De effectiviteit van deze maatregel is mogelijk afhankelijk van de grondsoort. Hier is een emissiereductie ingeschat van $25 \%$, waarbij dit leidt tot een emissie van $14 \%$ bij zodenbemesting (nog verder te onderbouwen).

\section{Toelichting praktische implementatie}

Aandacht voor goede werking zodenbemesting is momenteel op de achtergrond gekomen, omdat minder diep werken ook veelal geaccepteerd is. Het aspect 'alle mest goed in sleuven' moet weer onder de aandacht gebracht worden. Dit kan mogelijk ook leiden tot een schifting van te gebruiken machines (sommige machines worden 'zodenbemester' genoemd terwijl het te realiseren werkresultaat hiermee niet overeenkomt). Voorlichting, borging/handhaving, keuring machines, opleiding chauffeurs etc. zijn aspecten om de effectiviteit van de mesttoediening te verhogen. Daarnaast zijn er mogelijkheden om technieken toe te passen die de goede werking monitoren.

\section{Toelichting kosten}

Aangenomen wordt dat de meerkosten $€ 0,50$ per $\mathrm{m}^{3}$ mest. De meeste kosten zitten in extra arbeid.

In Nederland wordt 60 miljoen ton dierlijke mest uitgereden op 1 miljoen ha grasland. 60 miljoen ton

$* € 0,50$ per ton $=€ 30$ miljoen per jaar. Als in $202030 \%$ geïmplementeerd is, dan dus $30 \%$ van deze bedragen.

Een loonwerker rijdt $30 \mathrm{~m}^{3}$ mest per uur uit; $250 \mathrm{~m}^{3}$ per dag. Dit gedurende 120 dagen in het jaar, maakt $30.000 \mathrm{~m}^{3}$ per combinatie. Stel aanpassing machine geeft investering $€ 15.000$, dan is dat $€ 0,50$ per $\mathrm{m}^{3}$. 


\subsubsection{Factsheet 22. Mestinjectie op grasland}

\section{Mestinjectie op grasland (zandgrond)}

Injectie van mest op zandgrond (differentiëren van aanwendingstechniek naar grondsoort). Met injectie wordt hier bedoeld het werkresultaat van de 'oude' injecteur d.w.z. met afdichten injectiesleuf. Mestinjectie is vanuit trekkracht en bodemcondities niet altijd mogelijk op klei en veengrond. Op zandgrond zijn er wel goede ervaringen geweest in het verleden. Bij een eventuele herintroductie is er nog wel aandacht nodig voor de benodigde trekkracht (i.c.m. werkbreedte) en eventuele verdroging langs injectiesleuf (doorontwikkeling nieuwe injecteur naar laatste stand der techniek).

Voor de EF mestinjectie op grasland wordt $5 \%$ aangehouden.

\begin{tabular}{|l|c|c|}
\hline Effectiviteit reductie & $\mathbf{2 0 2 0}$ & $\mathbf{2 0 3 0}$ \\
\hline Bij landelijke maatregel: emissiedaling (kton N/jr) & 2,9 & $\mathbf{2 0 3 0}$ \\
\hline $\begin{array}{l}\text { Implementatie } \\
\text { (kosteneffectiviteit en tijdpad) }\end{array}$ & $\mathbf{2 0 2 0}$ & 0,8 \\
\hline Kosteneffectiviteit (M€/kton N) & 0,4 & 32 \\
\hline Investeringskosten voor de sector (M€) & \multicolumn{1}{|c|}{1,1} & 5,4 \\
\hline Operationele kosten voor de sector (M€/jr) & 5-10 jaar \\
\hline Tijd benodigd voor invoering maatregel (jr) & \begin{tabular}{l} 
5-10 jaar \\
\hline Termijn waarop effect wordt bereikt (jr)
\end{tabular} & $\begin{array}{l}\text { Verplicht, tenzij meerkosten voor veehouder } \\
\text { meevallen en effectiviteit mestbenutting goed is } \\
\text { en er weinig risico op schade is. }\end{array}$ \\
\hline Afdwingbaarheid en instrumentatie \\
\hline $\begin{array}{l}\text { Verplicht in te voeren via wet- en regelgeving } \\
\text { (ja/nee) }\end{array}$ & $\begin{array}{l}\text { Vrijwillig indien meerkosten voor veehouder } \\
\text { meevallen en effectiviteit mestbenutting goed is } \\
\text { en er weinig risico op schade is. }\end{array}$ \\
\hline $\begin{array}{l}\text { Vrijwillig in te voeren via kennisdeling en } \\
\text { stimulering (ja/nee) }\end{array}$ & \multicolumn{2}{|l}{} \\
\hline \begin{tabular}{l} 
Vrijwillige afspraak (ja/nee) \\
\hline
\end{tabular}
\end{tabular}

\section{Toelichting maatregel}

Bij injectie wordt hier bedoeld het werkresultaat van de 'oude' injecteur d.w.z. met het afdichten injectiesleuf. Mestinjectie is vanuit trekkracht en bodemcondities gezien niet altijd mogelijk op klei en veengrond en is daarom niet verplicht gesteld bij de introductie van emissiearme mesttoediening. Op zandgrond zijn er in het verleden wel goede ervaringen geweest. De ammoniakemissie kan aanzienlijk worden gereduceerd (Huijsmans et al., 1997).

\section{Toelichting praktische implementatie}

Ervaringen met mestinjectie uit het verleden (eind jaren '80) dienen in perspectief gezet te worden in relatie tot de huidige bemestingspraktijk (mestgiften, spreiding over het seizoen). Bij een eventuele herintroductie van mestinjectie zal deze techniek weer verder uitgewerkt en ontwikkeld moeten worden naar de laatste stand der techniek en inpassing mestgiften in de praktijk per bemestingsronde. Hierbij is nog wel aandacht nodig voor benodigde trekkracht (i.c.m. werkbreedte) en de eventuele kans op verdroging langs de injectiesleuven. Bij de berekeningen is uitgegaan van het gehele graslandareaal op zandgrond; bij herintroductie is het mogelijk beter om een deel van dit areaal op te nemen, waar de beste kans op slagen is (naar aanleiding van bodemomstandigheden). 


\section{Toelichting kosten}

Mestinjectie: kosten investering apparatuur vergelijkbaar met zodenbemester; capaciteit (werkbreedte) kleiner dus kost meer tijd, maar aan de andere kant mogelijk in één bemestingsronde een hogere mestgift mogelijk wat leidt tot een tijdbesparing. Indien mestinjectie naast een zodenbemester gaat worden toegepast dan betekent het wel een extra machine met mogelijk een lagere bezetting voor beide machines als hetzelfde areaal bemest moet worden.

Kosten in geval mestinjectie naast zodenbemester:

Investering zodenbemester (en injecteur): $€ 35.000$. Jaarkosten $17 \%=€ 6.000$. Hiermee kan 30.000 $\mathrm{m}^{3}$ per jaar bemest worden. Investering dus $€ 1,20$ per $\mathrm{m}^{3}$ en jaarkosten $€ 0,20$ per $\mathrm{m}^{3}$. Investering voor 26,4 miljoen $\mathrm{m}^{3}$ is $€ 32$ miljoen en jaarkosten $€ 5,4$ miljoen in 2030. Als in $202020 \%$ geïmplementeerd is, dan dus $20 \%$ van deze bedragen.

\subsubsection{Factsheet 23. Emissiebeperkende weersomstandigheden}

\section{Emissiebeperkende weersomstandigheden}

Gebruik maken van de voorspelbaarheid van lokale weersomstandigheden en de lokale mesttoediening afstemmen op emissiearme weerscondities. Data uitrijverbod (weersomstandigheden); differentiatie naar grondsoort.

Weersomstandigheden kort na uitrijden en aansluitende dagen spelen een rol bij hoogte optredende emissie. Inspelen op deze weersomstandigheden betekent inpassing in andere werkzaamheden, vragen over beschikbare capaciteit (loonwerker), toelaatbare bodemcondities en gewasstadium. Hier liggen mogelijke eerste opties voor mesttoediening op grasland.

Uitgegaan wordt van een emissiereductie van $25 \%$ bij zodenbemesting (ten opzichte van huidige emissiefactor van 19\%). In de berekeningen is uitgegaan van een emissiefactor van $14 \%$ voor zodenbemesting.

(Mogelijk straks nog wel onderscheid naar grondsoort)

\begin{tabular}{|c|c|c|}
\hline Effectiviteit reductie & 2020 & 2030 \\
\hline Bij landelijke maatregel: emissiedaling (kton $\mathrm{N} / \mathrm{jr}$ ) & 2,4 & 6,1 \\
\hline $\begin{array}{l}\text { Implementatie } \\
\text { (kosteneffectiviteit en tijdpad) }\end{array}$ & 2020 & 2030 \\
\hline Kosteneffectiviteit (M€/kton $\mathrm{N}$ ) & 2,3 & 4,4 \\
\hline Investeringskosten voor de sector (M€) & 32 & 160 \\
\hline Operationele kosten voor de sector ( $\mathrm{M} € / \mathrm{jr}$ ) & 5,4 & 27 \\
\hline Tijd benodigd voor invoering maatregel (jr) & \multicolumn{2}{|c|}{ 5-10 jaar } \\
\hline Termijn waarop effect wordt bereikt (jr) & \multicolumn{2}{|c|}{ 5-10 jaar } \\
\hline \multicolumn{3}{|l|}{ Afdwingbaarheid en instrumentatie } \\
\hline $\begin{array}{l}\text { Verplicht in te voeren via wet- en regelgeving } \\
\text { (ja/nee) }\end{array}$ & \multicolumn{2}{|c|}{ Mogelijk moeilijk te borgen. } \\
\hline $\begin{array}{l}\text { Vrijwillig in te voeren via kennisdeling en } \\
\text { stimulering (ja/nee) }\end{array}$ & \multicolumn{2}{|c|}{$\begin{array}{l}\text { Veel zal afhangen van arbeidsfilm op het bedrijf, } \\
\text { van de loonwerker en of er goede } \\
\text { omstandigheden zijn te vinden als de mest op } \\
\text { het veld gewenst is. }\end{array}$} \\
\hline Vrijwillige afspraak (ja/nee) & \multicolumn{2}{|l|}{ Zie stimulering. } \\
\hline
\end{tabular}




\section{Toelichting maatregel}

De weersomstandigheden kort na uitrijden en aansluitende dagen (temperatuur en windsnelheid) spelen een rol bij de hoogte van de optredende ammoniakemissie (Huijsmans et al., 2001; Søgaard et al., 2002). Inspelen op deze weersomstandigheden bij het uitrijden op basis van voorspelbaarheid kan bijdragen aan het verminderen van de emissie. Op basis van een paar eerste modelberekeningen lijkt een emissiereductie van $25 \%$ bij zodenbemesting mogelijk.

\section{Toelichting praktische implementatie}

Met de mesttoediening inspelen op emissiebeperkende weersomstandigheden betekent ook inpassing in andere werkzaamheden, vragen over beschikbare capaciteit (loonwerker), toelaatbare bodemcondities en gewasstadium bij die weersomstandigheden. Inspelen op de weersomstandigheden betekent in ieder geval dus vragen om flexibiliteit om het werk uit te voeren en een grotere beschikbare machinecapaciteit. Daarnaast vergt dit een andere aanpak voor de handhaving/borging.

\section{Toelichting kosten}

Weersomstandigheden: mikken op goede weersomstandigheden zal betekenen dat capaciteit voor mest uitrijden misschien wel meer dan verdubbeld moet worden om tijdig de mest uit te kunnen rijden binnen een areaal en dientengevolge hogere kosten.

In Nederland wordt 60 miljoen ton dierlijke mest uitgereden op 1 miljoen ha grasland.

Als per combinatie $30.000 \mathrm{~m}^{3}$ per jaar wordt gedaan, dan zijn er 2.000 combinaties nodig. Als dit moet verdubbelen en de investering per combinatie is $€ 80.000$ (100\% extra zodenbemesters, $50 \%$ extra tractoren), dan totale investering $€ 160$ miljoen. Jaarkosten hiervan zijn $€ 27$ miljoen. Als in $202020 \%$ geïmplementeerd is, dan dus $20 \%$ van deze bedragen. 


\section{Synthese}

Synthese Tabel. Verkorte beschrijving van de maatregelen uit de factsheets met reductie in 2020 en 2030 in kton/jr en de kosten per kton gereduceerde NH3-N voor 2020 en 2030. De bedragen zijn afgerond.

\begin{tabular}{|c|c|c|c|c|c|c|c|c|}
\hline \multirow[b]{2}{*}{ Toepassing } & & \multirow[b]{2}{*}{ Diercategorie } & & \multirow[b]{2}{*}{ Factsheetnr + Verkorte Maatregel } & \multicolumn{2}{|c|}{$\mathrm{NH} 3$ reductie, kton } & \multicolumn{2}{|c|}{ Kosten, M€/kton NH3-N } \\
\hline & & & & & 2020 & 2030 & 2020 & 2030 \\
\hline \multirow[t]{10}{*}{ Huisvesting } & Pluimvee & $\begin{array}{l}\text { Leghennen, } \\
\text { opfokleghennen }\end{array}$ & & 1 Dagontmesting met mestbanden & 0,6 & 1,4 & 7 & 10 \\
\hline & & Vleeskuikens & * & 2 Toepassen van turfstrooisel & 0,2 & 0,5 & 8 & 8 \\
\hline & & Vleeskuikens & & 3 By-pass van luchtwassers & 0,4 & 0,8 & 34 & 34 \\
\hline & Rundvee & Melkvee & * & 4 Verbetering mestschuiven met nieuwe mestschuiven & 0,7 & 2,1 & 15 & 15 \\
\hline & & & & 5 Bolle rubberen coating van roostervloer & 1,6 & 3,2 & 16 & 16 \\
\hline & & & * & 6 Ureaseremmers op stalvloer & - & 3,3 & - & 5 \\
\hline & & & & 7 Ventilatiemanagement gericht op beperkt debiet & 1,1 & - & 17 & - \\
\hline & & & * & 8 Luchtmixen van opgeslagen mest & 1,6 & 3,2 & 31 & 31 \\
\hline & & & & 9 Luchtzuivering in de nok & 0,5 & 3,1 & 35 & 35 \\
\hline & & & $*$ & 10 Luchtzuivering van lucht uit de kelder & 0,2 & 1,2 & 42 & 42 \\
\hline \multirow[t]{16}{*}{ Voeding } & Pluimvee & Vleeskuikens & $* *$ & 11 Eiwitgift op maat met hele tarwe $-10 \mathrm{~g} / \mathrm{kg} \mathrm{RE}$ & 0,2 & - & 2 & - \\
\hline & & Vleeskuikens & $* *$ & 12 Verfijning fasen voeding $-10 \mathrm{~g} / \mathrm{kg} \mathrm{RE}$ & 0,2 & - & 3 & - \\
\hline & & & $* *$ & 12 Verfijning fasen voeding $-20 \mathrm{~g} / \mathrm{kg} R E$ & - & 0,5 & - & 58 \\
\hline & & Vleeskuikens & $* *$ & 13 Verlagen eiwitgehalte voer $-20 \mathrm{~g} / \mathrm{kg} \mathrm{RE}$ & 0,8 & - & 35 & - \\
\hline & & & $* *$ & 13 Verlagen eiwitgehalte voer $-30 \mathrm{~g} / \mathrm{kg} \mathrm{RE}$ & - & 1,2 & - & 32 \\
\hline & & Leghennen & $* *$ & 14 Verlagen eiwitgehalte voer $-15 \mathrm{~g} / \mathrm{kg} \mathrm{RE}$ & 0,6 & - & 43 & - \\
\hline & & & $* *$ & 14 Verlagen eiwitgehalte voer $-25 \mathrm{~g} / \mathrm{kg} \mathrm{RE}$ & - & 1,1 & - & 39 \\
\hline & $\begin{array}{l}\text { Varkens } \\
* * * * *\end{array}$ & Zeugen met biggen & & 15a Verlagen eiwitgehalte $-10 \mathrm{~g} / \mathrm{kg} \mathrm{RE} \mathrm{g}+\mathrm{VCRE}-1 \%$ & 0,7 & - & $-0,7$ & - \\
\hline & & & & 15b Verlagen eiwitgehalte $-20 \mathrm{~g} / \mathrm{kg}$ RE + VCRE -1,5\% & - & 1,0 & - & 0,1 \\
\hline & & & $* * *$ & 16a Toevoeging van benzoëzuur voor biggen $5 \mathrm{~g} / \mathrm{kg}$ & 0,3 & - & 17 & - \\
\hline & & & $* * *$ & 16b Toevoeging van benzoëzuur voor biggen $10 \mathrm{~g} / \mathrm{kg}$ & - & 0,5 & - & 16 \\
\hline & & Vleesvarkens & & 17a Verlagen eiwitgehalte $-15 \mathrm{~g} / \mathrm{kg}$ RE + VCRE $-1 \%$ & 1,5 & - & 3 & - \\
\hline & & & & 17b Verlagen eiwitgehalte $-30 \mathrm{~g} / \mathrm{kg}$ RE + VCRE $-2 \%$ & - & 3,0 & - & 5 \\
\hline & & & $* * *$ & 18a Toevoeging van benzoëzuur $5 \mathrm{~g} / \mathrm{kg}$ & 0,6 & - & 24 & - \\
\hline & & & $* * *$ & 18b Toevoeging van benzoëzuur $10 \mathrm{~g} / \mathrm{kg}$ & 1,3 & - & 23 & - \\
\hline & Rundvee & Melkvee & $* * * *$ & 19 Voermaatregelen tbv reductie TAN excretie NL & 1,3 & 4,4 & Levert op & Levert op \\
\hline
\end{tabular}


Synthese Tabel. Verkorte beschrijving van de maatregelen uit de factsheets met reductie in 2020 en 2030 in kton/jr en de kosten per kton gereduceerde NH3-N voor 2020 en 2030. De bedragen zijn afgerond.

\begin{tabular}{|c|c|c|c|c|c|c|}
\hline \multirow[b]{2}{*}{ Toepassing } & \multirow[b]{2}{*}{ Diercategorie } & \multirow[b]{2}{*}{ Factsheetnr + Verkorte Maatregel } & \multicolumn{2}{|c|}{$\mathrm{NH} 3$ reductie, kton } & \multicolumn{2}{|c|}{ Kosten, $\mathrm{M} € /$ kton NH3-N } \\
\hline & & & 2020 & 2030 & 2020 & 2030 \\
\hline \multirow[t]{4}{*}{ Toediening } & & 20 Aanzuren mest i.c.m. emissiearme techniek & 2,4 & 6,1 & 20 & 39 \\
\hline & Rundvee & 21 Effectiviteit van huidige technieken verbeteren & 2,4 & 6,1 & 4 & 5 \\
\hline & /varkens & 22 Injectie mest op zandgrond & 2.9 & 7,2 & 0,4 & 0,8 \\
\hline & & 23 Emissiearme weerscondities & 2,4 & 6,1 & 2 & 4 \\
\hline
\end{tabular}

* Deze maatregelen zijn in ontwikkeling, maar moeten nog uitontwikkeld of gevalideerd worden.

** Voermaatregelen bij pluimvee zijn ongewis, is zeer afhankelijk van strooiselkwaliteit. De waarden in de tabel komen voor wanneer strooisel in de stal droog en rul is. Bij natter strooisel, waarvan de bovenlaag dichtslaat zijn voereffecten niet of nauwelijks zichtbaar.

*** Het voeren van benzoëzuur is duur. De kosten die verrekend zijn betreffen de hogere voerkosten. Echter, wat niet is meegenomen zijn de betere productiecijfers en gereduceerde antibioticakosten. Benzoëzuur heeft namelijk een gunstig effect op de gezondheid en de groei. Cijfers daarover zijn echter niet bekend. Wel kan geconstateerd worden dat benzoëzuur in de praktijk al wordt toegepast, vooral bij biggen.

**** Efficiëntieverbetering is in de veehouderij is een doorlopende autonome ontwikkeling, en derhalve niet enkel toe te schrijven aan de ammoniakemissiereductie

maatregel. Er kan wel gesteld worden dat de maatregel geld oplevert. Dit is daarom kwalitatief opgenomen in de tabel. Gehele doorberekening levert een voordeel op van ca. $30 € / \mathrm{kg} \mathrm{N}$

$* * * * *$ Voor varkens geldt dat ca. $40 \%$ van de dieren achter luchtwassers zit, het is niet logisch dat hier stal- of voermaatregelen genomen worden. De implementatie is dus ten hoogste $60 \%$. 


\section{Literatuur}

Aarnink, A.J.A., P. Bikker en J.T.M. van Diepen, 2012. Voermaatregelen voor ammoniakreductie in stallen voor zeugen en biggen. Wageningen Livestock Research, Rapport $591-22$ p.

Bussink, D.W., J.F.M. Huijsmans \& J.J.M.H. Ketelaars, 1994. Ammonia volatilization from nitric-acidtreated cattle slurry, (surface) applied to grassland. Netherlands Journal of Agricultural Science 42: 293-309.

Bussink, D.W., Rotterdam-Los, A.M.D. van, Vermeij, I., Dooren, H.J.C. van, Bokma, S., Ouwerkerk, G.J. Draai, H. van der, Wenzl, W., 2014. Reducing NH3 emissions from cattle slurry by (biological) acidification: experimental proof and practical feasibility. Report 1422.N.12. Wageningen, Nutriënten Management Instituut (NMI).

Ellen, H. en N.W.M. Ogink, 2015. Effecten reducerende technieken op emissies bij biologisch gehouden pluimvee; Deskstudie. Lelystad, Wageningen UR (University \& Research Centre) Livestock Research, Livestock Research Report 811.32 blz.

Ellen, H.H., C.M. Groenestein, N.W.M. Ogink , 2017. Actualisering ammoniak emissiefactoren pluimvee; Advies voor aanpassing van ammoniak emissiefactoren van pluimvee in de Regeling ammoniak en veehouderij (Rav). Wageningen Livestock Research, Rapport 1015 - 60 p.

Huijsmans, J.F.M., J.M.G. Hol \& B.W. Bussink, 1997. Reduction of Ammonia Emission by New Slurry Application Techniques on Grassland. In: S.C. Jarvis \& B.F. Pain (Eds.) Gaseous Nitrogen Emissions from Grasslands. CAB International, Wallingford, pp. 281-285.

Huijsmans, J.F.M., J.M.G. Hol \& M.M.W.B. Hendriks, 2001. Effect of application technique, manure characteristics, weather and field conditions on ammonia volatilization from manure applied to grassland. Netherlands Journal of Agricultural Science 49: 323-342

Huijsmans, J.F.M. \& R.L.M. Schils (2009). Ammonia and nitrous oxide emissions following fieldapplication of manure: state of art measurements in the Netherlands. Proceedings 655, International Fertiliser Society, $35 \mathrm{pp}$.

Huijsmans, J.F.M.; Hol, J.M.G.; Schooten, H.A. van (2015). Toediening van aangezuurde mest met een sleepvoetenmachine op grasland: ammoniakemissie en gewasopbrengst. Wageningen: Plant Research International, onderdeel van Wageningen UR, Business Unit Agrosysteemkunde, Plant Research International Rapport 629 - 45 p.

Melse, R.W., Starmans, D.A.J. en Ogink, N.W.M., 2015. Aanzuursystemen voor rundveedrijfmest in stallen. Livestock Research Rapport 898. Wageningen UR Livestock Research, Wageningen.

Søgaard, H.T., S.G. Sommer, N.J. Hutchings, J.F.M. Huijsmans, D.W. Bussink \& F. Nicholson, 2002. Ammonia volatilization from field-applied animal manure-the ALFAM model. Atmospheric Environment 36: 3309-3319.

Van Harn, J., G. Nijeboer en N. Ogink, 2015. Effect van snijmaissilage als strooiselmateriaal in vleeskuikenstallen op de emissies van ammoniak, geur, fijnstof, methaan en lachgas (Effect of silage maize as bedding material in broiler houses on the emissions of ammonia, odour, PM10, methane and nitrous oxide). Wageningen, Wageningen UR (University \& Research centre) Livestock Research, Livestock Research Rapport 845, 49 blz.

Harn, J. van, T. Veldkamp. 2006. ASG-onderzoek met 'voeren op maat' - soms beter, soms slechter. Pluimveehouderij 36, 11 februari: 16-18.

Veldkamp, T., Star, L., Klis, J.D. van der, Harn, J. van, 2012. Reductie van ammoniakemissie op pluimveebedrijven via voeding (Reduction of ammonia emission from poultry houses by nutrition). Wageningen UR Livestock Research Rapport 490 - 38 p.

Winkel, A. ; Ellen, H.H. ; Ogink, N.W.M. (2014) Mogelijkheden voor het vaststellen van emissies van leghennenstallen met een nageschakeld mestdroogsysteem $=$ Possibilities for determining emissions of laying hen houses connected to a manure drying system. Lelystad : Wageningen UR Livestock Research, (Report / Wageningen UR Livestock Research 803) - 20 p. 


\section{Bijlage 1 Groslijst van maatregelen reservepakket}

De maatregelen die in onderstaand overzicht het meest kansrijk/effectief worden geacht zijn vet gedrukt en met een * gemarkeerd.

\section{Mesttoediening grasland en bouwland}

Geheel nieuwe toedieningstechnieken zijn niet gelijk te verwachten. Hier zal gezocht moeten worden naar combinaties van bestaande maatregelen en verbetering van de uitvoering. Opties ook om maatregelen te differentiëren naar grondsoort.

- Zodenbemester en sleepvoeten in combinatie met aanzuren mest voor aanwending; sleepvoet en zwavelzuur is onderzocht; opties voor andere zuren.*

- Effectiviteit van huidige technieken verbeteren; nauwkeurigheid van werken op grasland en bouwland; differentiatie naar grondsoort.*

- Injectie mest op zandgrond (differentiëren van aanwendingstechniek naar grondsoort); injectie hier bedoeld als werkresultaat 'oude' injecteur d.w.z. met afdichten injectiesleuf, echter nu aansluitend/ontwikkeling naar laatste stand der techniek.*

- $\quad$ Effectiviteit verschillende mestsoorten of mestbewerkingsprodukten (bv mest scheiden en alleen dunne fractie toedienen, vergiste mest).

- Injectie/direct inwerken op onbeteeld bouwland i.p.v. zodenbemesting; differentiatie naar grondsoort.

- Geen vaste mest meer op grasland.

- Gebruik maken van voorspelbaarheid lokale weersomstandigheden en lokale toediening afstemmen op emissiearme weerscondities. Data uitrijverbod (weersomstandigheden); differentiatie naar grondsoort. Verbetering van de effectiviteit van uitvoering bestaande maatregelen via verbeterde borging.*

- Gewas, bodem, precisielandbouw..... aankomende mogelijkheden innovaties.

\section{Huisvesting}

Hierbij moet onderscheid gemaakt worden naar maatregelen die in bestaande stallen kunnen worden toegepast en maatregelen die alleen bij volledige stalinnovatie mogelijk zijn. Voor een snel implementatie-effect zijn met name de maatregelen die in bestaande stallen kunnen worden toegepast van belang.

- Verbetering mestschuif-uitvoering en management voor verbeterde directe afstroming gier, in zowel conventionele roostervloerstallen als stallen met emissiearme vloer.*

- Coating van roostervloer in bestaande stallen, toevoegen rubberen toplaag aan roostervloer voor verbeterde afstroming gier.*

- Inzet van ureaseremmers op stalvloer.*

- Dakisolatie waardoor stalklimaat stabieler wordt en minder ventilatie nodig is.

- Ventilatiemanagement gericht op beperkt debiet.*

- Kelderemissie verminderen door vermijden laagvorming met verschillende samenstelling, te bereiken door frequent mengen opgeslagen mest.*

- Kelderemissie verminderen door stro toe te voegen om zo emissie toplaag in kelder te verminderen.

- $\quad$ Afdekken van de mest in de kelder via mestballen.

- Koelen keldermest bv in combinatie hergebruik warmte.

- Effectieve inpassing van luchtzuiveringssystemen in melkveestal zonder het open karakter van de stal aan te tasten, door zuivering in de nok en/of van lucht uit de kelder via onderafzuiging.* 
- Grasmanagement, inclusief teelt/veredeling N-efficiënte grassen: denk aan oogstmoment optimaliseren, graslandvernieuwing optimaliseren, grasmengsels aanpassen.

- $\quad$ Afspreken + afdwingen maximale eiwitniveaus in rantsoenen (bv max. 15\% ruw eiwit in rundveerantsoenen). De afgesproken maatregelen worden nu nog niet effectief uitgevoerd.

- Kation/anion verhouding in het voer voor verlaging $\mathrm{pH}$ (alle diercategorieën inclusief rundvee).

- $\quad$ Toepassing voeremissiemodellen voor kwantificering effecten emissiearm voeren in varkensen pluimveecategorieën.

- $\quad$ Stimuleren weidegang en betere borging via controle op melkvetzuur-samenstelling.

- Benchmark opstellen Kringloopwijzer/BEA om te komen tot (regionaal) gedifferentieerde kengetallen ten behoeve van vermindering ammoniakemissies (en andere emissies/verliezen fosfaat, methaan, lachgas) in de melkveehouderij.

- Idem benchmark efficiëntie cijfers voor stalbalansen varkenshouderij en pluimveehouderij.

Suggesties pluimveehouderij

- Strooiselbehandeling (gebruik toevoegmiddelen sprayen of mengen, zoals zeoliet e.d. om ammoniak te binden)? En wat is er zoal meer mogelijk?

- Type strooisel, wat doet turf/turfstrooisel: geeft dat ook minder ammoniak, net als snijmaissilage? Turf heeft van natura ook een lagere $\mathrm{pH} / \mathrm{hogere}$ zuurgraad.

- Ventilatiedebiet in stal verlagen (minder debiet = minder emissie) ventilatiewijze; welke opties zijn er voor gangbare stallen (dat het niet direct een Terra Sea moet worden) of hoe is dit te realiseren (aanbouw?) (conditioneren? Hoeveel effect kunnen we verwachten).

- $\quad$ Gelijkdruk ventilatiesystemen (zuigen minder stof uit de stal)? Zoals vrij gebruikelijk aan het worden is bij freilandstallen? Lijkt me zeer perspectiefvol (ook op het spoor van minder debiet).

- Gebruik van natuurlijke ventilatie leidt zeer waarschijnlijk tot minder fijnstofuitstoot om dat het debiet veel lager is dan mechanisch geventileerde stallen.

- Door het gebruik van een waterwisselaar lager/geen risico op nat strooisel en daarmee geen/minder ammoniak (om koud bronwater met wisselaar op temperatuur te brengen waardoor geen condens aan leidingen en kuikens niet ziek van te koud water dus darmstoornissen vermijden).

- Veegpoeder; veegpoeder absorbeert en bindt stof, wordt bij verbouw van supermarkten bijvoorbeeld gebruikt om stof te binden zodat niet de hele toko onder het stof komt; is humaan ok want arbeidsvoorwaarden wordt strak op toegezien; zou dit iets zijn om op de vloer aan te brengen, strooisel er over heen, wat vervolgens (fijn)stof en ammoniak bindt (of minder laat vervluchtigen)? Of periodiek bijstrooien?

- Dagontmesting van mestbandsystemen in stal (volière, maar ook bij mestband onder beun); waarschijnlijk zeer perspectiefvol en grote reductie; dit wel i.c.m. achterliggend mestdroogsysteem zien (verschillende varianten mogelijk).

- By-pas van luchtwassers; WUR heeft hier jaren terug al onderzoek naar gedaan, zou zo geïmplementeerd kunnen worden. Niet als generieke maatregel maar wel als lokale oplossing voor bepaalde ondernemers.

- Ionisatie-verlichting: heeft dit ook een reducerend effect op ammoniak (naast fijnstof)?

- Geeft een hogere capaciteit van de warmtewisselaar bv. $1 \mathrm{~m}^{3}$ i.p.v. 0,35 $\mathrm{m}^{3}$ per dier per uur zoals dat voor fijnstof gebruikelijk is nog extra reductie voor ammoniak?

- Is er onderscheid tussen warmtewisselaars met inbreng via buis onder de nok of louvre box vs. inbreng via plastic slangen boven het strooisel (die naast het inbrengen van voorverwarmde lucht wat meer vocht kan opnemen ook het strooiseloppervlak plaatselijk belucht)?

- Het gebruik van een opfokgedeelte in de stal (met zo'n tijdelijke opblaasscheidingswand bijvoorbeeld) en daarna herverdelen over de hele stal; leidt dat tot lagere emissie (netto verblijftijd betreft dan kleiner emitterend oppervlak)?

Het pakketje voermanagement maatregelen vraagt nog een nadere beschouwing omdat er overlap kan zitten met de uitwerking van maatregelen in het kader van het fosfaatbeleid 2017 en maatregelen die verondersteld worden te vallen onder de huidige lopende overeenkomst generieke maatregelen. 


\section{Bijlage 2 Referentiesystemen t.b.v. behoeve van ammoniakemissie- reductie berekening van Facsheet 1: Dagontmesting met mestbandsystemen}

De referentie voor volière- en kooisystemen is $1 \mathrm{x}$ per week afdraaien van beluchte mest. Dit systeem kent geen referentie voor grondhuisvesting omdat hier geen of nauwelijks sprake is van mestbanden. Bovendien neemt aandeel grondhuisvesting naar verwachting af. Er zijn 5 volièresystemen voor leghennen (E 2.11.1, E 2.11.2.1; E 2.11.2.2; E 2.11.3; E 2.11.4) en 6 voor opfokleghennen (E 1.8.1, $E$ 1.8.2; E 1.8.3.1; E 1.8.3.2; E 1.8.4; E 1.8.5) die als referentie dienen voor volièrestallen. Volgens Winkel et al., 2014 (rapport 803) is een ammoniakemissiereductie van $30 \%$ mogelijk bij dagontmesting in een voliérestal.

Voor de kooisystemen voor leghennen met 1x per week afdraaien en beluchting zijn er 2 referenties (E 2.5.5 en E 2.5.6). Voor kooihuisvesting is de reductie hoger omdat alle mest via de band verwijderd wordt en er geen strooisel in de stal is. De reductie is voor kooihuisvesting derhalve geschat op 55\% (Winkel e tal., 2014).

Tabel 1 geeft een reële schatting van de implementatie van huisvestingssystemen in 2012-2014 en een inschatting van de implementatie voor 2020 en 2030 afhankelijk van de tijd die nodig is voor de invoering van de maatregel.

Tabel 1. Aandeel van leghennen en opfokleghennen in volièrehuisvesting, kooihuisvesting en grondhuisvesting met en zonder droogtunnel voor de referentiejaren 2012-2014, 2020 en 2030.

\begin{tabular}{|l|l|l|c|c|c|}
\hline & & & $2012-2014$ & 2020 & 2030 \\
\hline Leghennen & volière & Droogtunnel & 0.15 & 0.35 & 0.85 \\
\hline & & Geen droogtunnel & 0.45 & 0.35 & 0.15 \\
\hline & kooi & Droogtunnel & 0.05 & 0.1 & 0 \\
\hline & & Geen droogtunnel & 0.15 & 0.1 & 0.1 \\
\hline & grond & & 0.2 & 0.1 & 0.15 \\
\hline & volière & Droogtunnel & 0.15 & 0.35 & 0.35 \\
\hline & & Geen droogtunnel & 0.45 & 0.1 & 0.1 \\
\hline
\end{tabular}

De investeringskosten zijn berekend ervan uitgaande dat droogtunnels in 2012-2014 al bij 20\% van de dieren geïmplementeerd is. Dat betekent dat $80 \%$ van de dieren nog voorzien moeten worden van een droogtunnel. Tot 2020 is de verwachting dat deze ontwikkeling autonoom en onder invloed van het huidige Besluit emissiearme huisvesting verloopt. Voor de overige 55\% zal naar verwachting een stimuleringsregeling nodig zijn. Voor de $20 \%$ van de dieren van wie de mest al met een droogtunnel gedroogd wordt zijn geen extra kosten van toepassing (het meerdere keren afdraaien van de banden kost een verwaarloosbare hoeveelheid energie, ook het extra energieverbruik van de droogtunnel kan verwaarloosd worden (Ellen, persoonlijke mededeling). 


\title{
Bijlage 3 Achtergrondinformatie bij Facsheet 19: TAN-excretie verminderen op het melkveebedrijf met voermaatregelen
}

\begin{abstract}
Achtergrond
De bron van ammoniakemissie op een veehouderijbedrijf is de hoeveelheid ammoniakaal stikstof (TAN in $\mathrm{kg}$ per jaar) die door de veestapel wordt geproduceerd. Een effectieve maatregel om de ammoniakemissie te verlagen is dan ook het verlagen van de TAN-excretie door de veestapel. Toepassen van deze doelmaatregel gebeurt via het voer- en diermanagement en is daarmee een pakket van maatregelen. Vrijwel ieder Nederlands melkveebedrijf kan in dat pakket passende maatregelen vinden. Het gaat daarbij niet om de toepassing van afzonderlijke voermaatregelen, maar om de combinatie van maatregelen. Uitvoering van deze maatregelen kan alleen als de melkveehouder goede informatie krijgt over de gerealiseerde TAN-excretie. De module Bedrijfsspecifieke Emissie Ammoniak (BEA) van de Kringloopwijzer is een methodiek waarmee voor een melkveebedrijf de gerealiseerde TAN-excretie vastgesteld kan worden.
\end{abstract}

\section{Inschatten effect van het verlagen van de TAN-excretie op het melkveebedrijf}

De reductiemogelijkheden voor de TAN-excretie kan met enkele kengetallen worden ingeschat. Door voor die kengetallen een in de praktijk haalbare uiterste waarde (maximum dan wel minimum) te definiëren en die te vergelijken met de actuele waarde (Tabel 1) wordt duidelijk wat de geschatte reductiepotentie in $\mathrm{kg}$ TAN is. De gemiddelde NL waarde van kengetallen is gebaseerd op data van de WUM en voor 2014 is die referentie gelijk aan het gemiddelde van de jaren 2012, 2013 en 2014 zoals vastgesteld door de WUM. Vervolgens is voor de kengetallen een uiterste waarde ingeschat (let op: op basis van expert judgement en dat zou breder getoetst kunnen/moeten worden).

Tabel 1. Kengetallen TAN-excretie van melkvee op basis van WUM, inclusief ontwikkeling van 19902014 en minimale dan wel maximale waarden (ingeschat).

Regio

nr Kengetal

Verteringscoëfficiënt ruw eiwit

(VC-re in \%)

2 Ruwe eiwitgehalte rantsoen

2 (g re/kg droge stof)

3 Voeropname

3 (in kg per dier per dag)

4 Melkproductie

5 Voerefficiëntie

(kg FPCM ${ }^{1}$ per kg opgenomen droge stof)

6 N-benutting

( $\mathrm{N}$ in melk/opgenomen verteerbare $\mathrm{N}$, in \%)

$7^{N}$-efficiëntie

( $\mathrm{N}$ in melk / opgenomen $\mathrm{N}$, in \%)
4 (kg FPCM ${ }^{1}$ per dier per jaar)

NL

1990

2014

NW

zo$$
80,
$$$$
73,7
$$

$\max$

$\min$

Max $\min$

$\begin{array}{ccccccc}80,1 & 73,7 & - & 70,0 & - & 70,0 \\ 202,1 & 160,4 & - & 145 & - & 140 \\ 15,2 & 18,0 & - & - & - & - \\ & & & & & \\ 6300 & 8445 & 10000 & - & 11000 & - \\ & & & & & \\ 1,085 & 1,224 & 1,4 & - & 1,5 & - \\ & & & & & \\ 24,1 & 37,2 & 45,0 & - & 50,0 & - \\ 19,3 & 27,4 & 35,0 & - & 35,0 & -\end{array}$

${ }^{1}$ FPCM $=$ Fat and Protein Corrected Milk (gestandaardiseerde melkproductie c.q. meetmelk) 
Vervolgens is ingeschat of en, zo ja hoe, die kengetallen zich gaan ontwikkelen naar de ingeschatte uiterste waarden en dan met name voor 2020 en 2030. De aangenomen ontwikkeling is in principe een extrapolatie van de ontwikkeling van die kengetallen in de periode 1990-2014 (op basis van WUM), maar de extrapolatie heeft als eindpunt de ingeschatte uiterste waarde (minimum dan wel maximum). Vervolgens is met die informatie de TAN-excretie voor zowel de referentie als de jaren 2020 en 2030 doorgerekend (Tabel 2) en het verschil met de actuele TAN-excretie (benchmark) geeft dan de potentiële emissiereductie voor de maatregel 'verminderen TAN-excretie'.

Tabel 2. Berekende kengetallen en TAN-excretie van melkvee voor de referentie (benchmark) en voor de jaren 2020 en 2030 na het nemen van voermaatregelen.

\begin{tabular}{|c|c|c|c|c|c|c|c|c|c|c|}
\hline & & & & & \multicolumn{5}{|c|}{ Per dier per dag } & \\
\hline & & & $\mathrm{g} / \mathrm{kg} \mathrm{ds}$ & kg/jaar & & kg/dag & & & kg/jaar & \\
\hline & & VC_re & RE rants & FPCM & voereff & DSopn & Neff & Nbenut & TANtot & \\
\hline & & & & & & & & & & \\
\hline gemiddeld & $\mathrm{O}+\mathrm{Z}$ & 0,715 & 149,3 & 8606 & 1,30 & 18,1 & 0,295 & 0,412 & 194,0 & \\
\hline 2012-2014 & $\mathrm{N}+\mathrm{W}$ & 0,754 & 171,7 & 8274 & 1,26 & 18,1 & 0,247 & 0,328 & 263,3 & \\
\hline Benchmark & NL & 0,732 & 158,5 & 8453 & 1,28 & 18,1 & 0,273 & 0,373 & 222,8 & \\
\hline & & & & & & & & & & reductie $\%$ \\
\hline & & & & & & & & & & tov benchmark \\
\hline 2020 & $\mathrm{O}+\mathrm{Z}$ & 0,709 & 144,0 & 8971 & 1,33 & 18,5 & 0,312 & 0,440 & 181,5 & $-0,064$ \\
\hline & $\mathrm{N}+\mathrm{W}$ & 0,748 & 166,5 & 8625 & 1,28 & 18,4 & 0,260 & 0,348 & 251,3 & $-0,046$ \\
\hline & $\mathrm{NL}$ & 0,727 & 154,3 & 8812 & 1,31 & 18,4 & 0,286 & 0,394 & 213,0 & $-0,044$ \\
\hline 2030 & $\mathrm{O}+\mathrm{Z}$ & 0,700 & 140,0 & 10187 & 1,42 & 19,7 & 0,340 & 0,486 & 171,5 & $-0,116$ \\
\hline & $\mathrm{N}+\mathrm{W}$ & 0,728 & 149,1 & 9794 & 1,37 & 19,6 & 0,309 & 0,424 & 208,5 & $-0,208$ \\
\hline & NL & 0,713 & 144,2 & 10007 & 1,40 & 19,6 & 0,325 & 0,457 & 188,3 & $-0,155$ \\
\hline
\end{tabular}

Uit Tabel 2 blijkt dat er met voermaatregelen voor de melkveestapel een reductie van de ammoniakemissie mogelijk is ten opzichte van 2012-2014 van ca 5\% in 2020 en ca $15 \%$ in 2030 . Tot 2020 kan in de regio Zuid-Oost een iets grotere reductie gehaald worden dan in de regio Noord West $(6,4 \%$ vs. $4,6 \%)$, maar in 2030 is dat omgekeerd (11,6\% vs. $20,8 \%)$. De reden hiervoor is dat bij de gevolgde uitgangspunten (de min en max in tabel 1) de regio Zuid Oost bij extrapolatie van de trend 1990-2014 eerder een uiterste randvoorwaarde bereikt. Voor die regio wordt dus eerder de maximale reductiepotentie gerealiseerd. De kengetallen waar die uiterste waarde voor wordt bereikt zijn het re-gehalte in het rantsoen en de VC-re. 

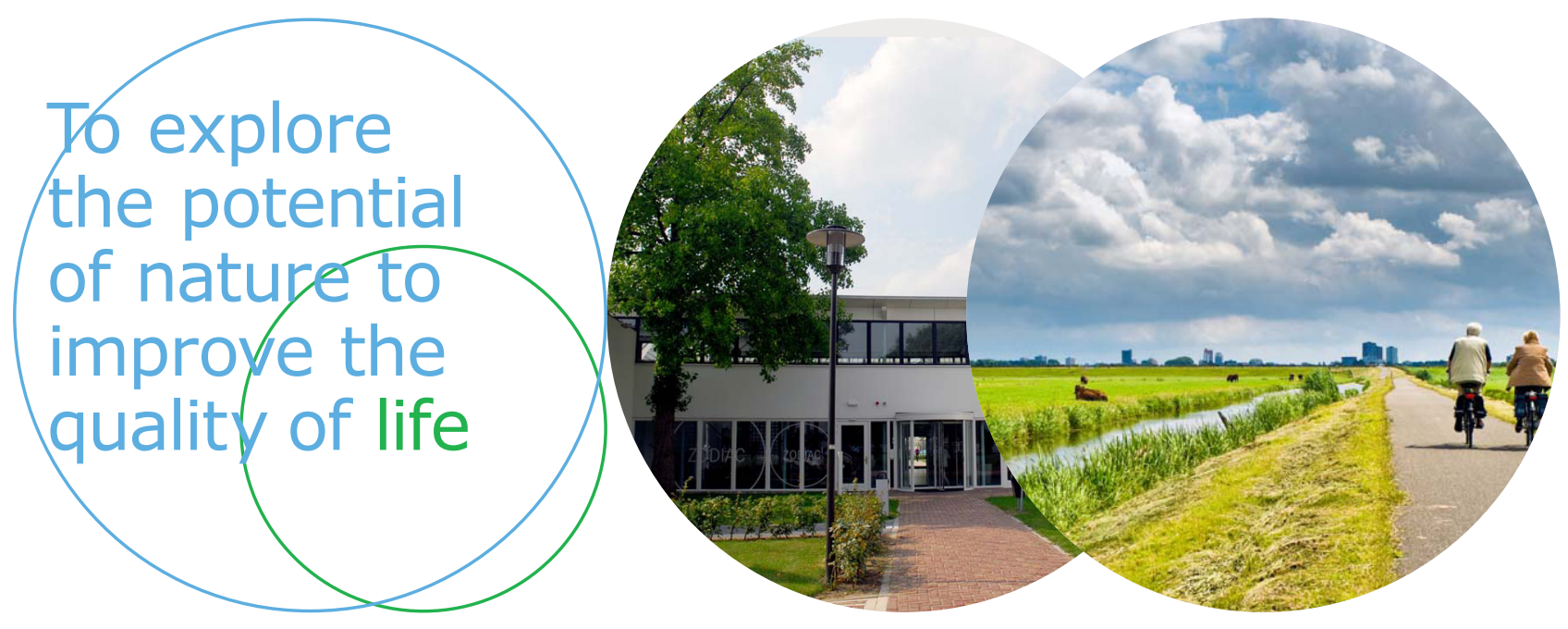

Wageningen Livestock Research Postbus 338

Wageningen Livestock Research ontwikkelt kennis voor een zorgvuldige en 6700 AH Wageningen

T 0317483953

renderende veehouderij, vertaalt deze naar praktijkgerichte oplossingen en innovaties, en zorgt voor doorstroming van deze kennis. Onze wetenschappelijke

E info.livestockresearch@wur.nl www.wur.nl/ livestock-research kennis op het gebied van veehouderijsystemen en van voeding, genetica, welzijn en milieu-impact van landbouwhuisdieren integreren we, samen met onze klanten, tot veehouderijconcepten voor de $21 \mathrm{e}$ eeuw.

De missie van Wageningen University \& Research is 'To explore the potential of nature to improve the quality of life'. Binnen Wageningen University \& Research bundelen 9 gespecialiseerde onderzoeksinstituten van Stichting Wageningen Research en Wageningen University hun krachten om bij te dragen aan de oplossing van belangrijke vragen in het domein van gezonde voeding en leefomgeving. Met ongeveer 30 vestigingen, 6.500 medewerkers en 10.000 studenten behoort Wageningen University \& Research wereldwijd tot de aansprekende kennisinstellingen binnen haar domein. De integrale benadering van de vraagstukken en de samenwerking tussen verschillende disciplines vormen het hart van de unieke Wageningen aanpak. 